\title{
A Deep Insight into the Application of Linear Free Energy Relationships (LFER) to Five Membered Heterocyclic Ring Systems: A Review
}

\author{
R. Sanjeev ${ }^{1}$, and V. Jagannadham ${ }^{2 *}$ \\ ${ }^{1}$ Department of Chemistry, Geethanjali College of Engineering and Technology, \\ Cheeryal-501301, Telangana, India \\ and \\ ${ }^{2}$ Department of Chemistry, Osmania University, Hyderabad-500007, India \\ Email: jagannadham1950@yahoo.com
}

\begin{abstract}
Hammett and Taft equations are applied to the acid dissociation equilibriums of 4 and 5-substituted furan, pyrrole, thiophene, tellurophen, isoxazole, pyrazole carboxylic acids, to solvolysis data of 4 and 5-substituted-2-furylmethylcarbinyl p-nitrobenzoates and to the permanganate ion oxidation of 5-substituted-2-furfurals. Excellent correlations were observed in these studies except in the case of 1-Me-4/5-X-3-pyrazole-COOH. In the case of 5-X-2furoic, pyrrole, thiophene carboxylic acids only the substituent - $\mathrm{COOH}$ deviated from these correlations for which possible explanation is given in terms of intramolecular hydrogen bonding between the $-\mathrm{COOH}$ and the ring heteroatom and two types of intramolecular hydrogen bonding between $-\mathrm{COOH}$ and ring nitrogen atom and $-\mathrm{COOH}$ and $\mathrm{H}$ of $\mathrm{NH}$ of pyrrole. In the case of 3,5-X-4-isoxazole carboxylic acids the $-\mathrm{NH}_{2}$ group at 5 position deviated for which the explanation in terms of $\mathrm{H}$-bonding between $-\mathrm{NH}_{2}$ and $-\mathrm{COOH}$ is given. Even the possibility of the formation of zwitterion is not ruled out. 5-X-1, 2, 3triazole-4-carboxylic acids did not follow any LFER. The solvolysis rate constants of both 4 and 5-substituted-2-furylmethylcarbinyl p-nitrobenzoates correlated well with para substituent constants. Further the correlation with Brown's $\sigma^{+}$values is still better. It is noteworthy that $\mathrm{MnO}_{4}^{-}$oxidation of 5-X-2-furfural correlated well with all the para, meta and ortho substituent constants. An attempt is made for the first time from our laboratory to apply the LFER to 5 membered ring systems with one heteroatom viz. pyrroles, two heteroatoms viz. pyrazoles, imidazoles, isoxazoles, three heteroatoms viz. the triazoles and four heteroatoms viz. tetrazoles. For the first time we have shown that the $\mathrm{p} K_{\mathrm{a}}$ values of $\mathrm{N}(1) \mathrm{H}-$ acidities of 3-X-pyrroles, 3-X-pyrazoles, 4-X-pyrazoles, 4-X-imidazoles, 3-X-1,2,4-triazole, 4-X-1,2,3-triazole and 5-X-1,2,3,4-tetrazoles correlated well with Hammett $\sigma$ values.
\end{abstract}

Keywords: Hammett equation; Taft equation; 5-membered heterocycles

Introduction: Use of Hammett equation [1-4] dealing with meta and para-substituted benzene derivatives and Taft equation $[5,6]$ dealing with ortho-substituted benzene derivatives in elucidating the reaction mechanisms in organic chemistry is indubitable. Since their introduction [1-6] numerous publications have appeared in literature [3,4] and still being published to date. Application of Hammett equation and Taft equation to five membered aromatic heterocyclic ring systems was less commonly studied. The first 
application of Hammett law (not as an equation) [7] to furan ring was with 5-X-2-furoic acids [8]. But this was quoted in reference [9] as it was published in 1935 [10] even before the Hammett equation came into existence. In reference [9] by Freeman it is surprising to see even a Hammett $\rho$ value was reported for the dissociation of 5-X-2-furoic acids without knowing Hammett $\sigma$ values because evaluation of Hammett $\sigma$ values took place only in 1937 [1]. In spite of numerous works on the application of Hammett and Taft equations in organic chemistry, their application to five membered ring systems did not find much place in chemistry research $[8,11]$ except a one-page small publication appeared 50 years ago [9] and references cited there in. In this publication [9] the information of substituents in furan and thiophene derivatives used did not find a place. In the present work we tried a deep insight with a total of 12 heterocyclic systems.

Experimental Data Source: All the linear correlations were done using the KaleidaGraph software, Reading, PA, USA. The chemical structures are drawn using chemdraw software.

\section{Results and discussion:}

Visual observation of benzene and five membered heterocycles to look for the similarity of para, meta and ortho-carbons of benzene and $5^{\text {th }}, 4^{\text {th }}$ and $3^{\text {rd }}$ carbons of five membered 5 or 4- or 3-(X)-2-(Y)-heterocycles:

As shown in scheme 1, it is known that all the six carbon atoms in the benzene ring are sp2 hybridized and benzene is a planar hexagon molecule.

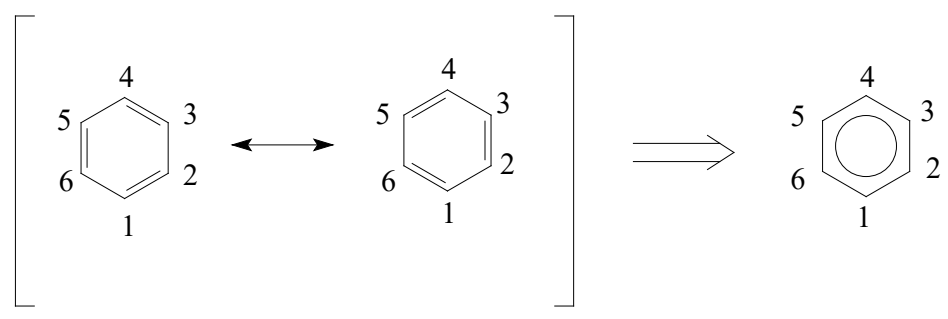

Scheme 1

This explains an equal possibility for the formation of $\mathrm{C} 1-\mathrm{C} 2, \mathrm{C} 3-\mathrm{C} 4, \mathrm{C} 5-\mathrm{C} 6 \pi$ bonds or $\mathrm{C} 2-\mathrm{C} 3, \mathrm{C} 4-\mathrm{C} 5, \mathrm{C} 6-\mathrm{C} 1 \pi$ bonds. The hybrid structure is represented by inserting a circle in the ring as shown above in the scheme 1. Hence, it explains the formation of two resonance structures proposed by Kekule [12] and they will always be in dynamic equilibrium. 


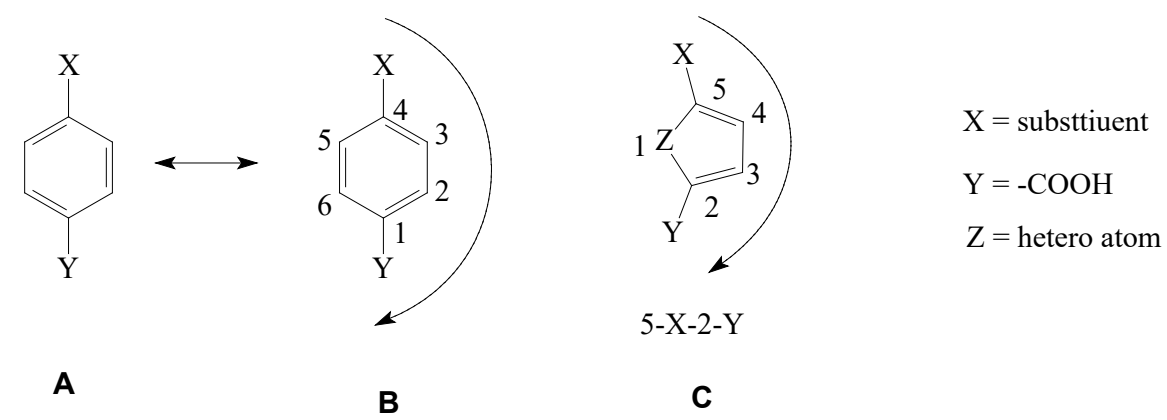

Scheme 2

At any given point of time during the dynamic equilibrium process of benzene, the statistical percentage of existence of either $\mathbf{A}$ and $\mathbf{B}$ in scheme 2 is 50:50. Now comparing the structure $\mathbf{B}$ and the structure of the 5-X-2-Y-heterocycle $\mathbf{C}$ of scheme 2, the functional group $\mathrm{Y}$ and the substituent $\mathrm{X}$ are separated by one single bond and two double bonds or simply by two pairs of $\pi$-electrons in benzene ring $\mathbf{B}$ and the heterocycle $\mathbf{C}$. Therefore, it can be assumed that the substituent electronic effects can be transmitted from carbon 4 bearing the substituent $\mathrm{X}$ to the functional group $\mathrm{Y}$ at carbon 1 of the benzene. This kind of situation of the structure C where in the substituent electronic effects can be transmitted from carbon 5 bearing the substituent $\mathrm{X}$ to the functional group $\mathrm{Y}$ at carbon 2 of the hetercycle would be just like that of structure B. Therefore carbon 5 of the structure $\mathbf{C}$ of scheme 2 could best be assumed as a para-carbon.

Similarly, now comparing the structure $\mathbf{E}$ and the structure of the 4-X-2-Y-heterocycle $\mathbf{F}$ of scheme 3, the functional group $\mathrm{Y}$ and the substituent $\mathrm{X}$ are separated by one single bond and one double bond or simply by a pair of $\pi$-electrons. It can be assumed that the substituent electronic effects can be transmitted from carbon 3 bearing the substituent $\mathrm{X}$ to the functional group $\mathrm{Y}$ at carbon 1 of the benzene. This kind of situation of the structure $\mathbf{F}$ where in the substituent electronic effects can be transmitted from carbon 4 bearing the substituent $\mathrm{X}$ to the functional group $\mathrm{Y}$ at carbon 2 of the hetercycle would be just like that of structure $\mathbf{E}$. Therefore, the carbon 4 of the structure $\mathbf{F}$ could best be assumed as a meta-carbon.

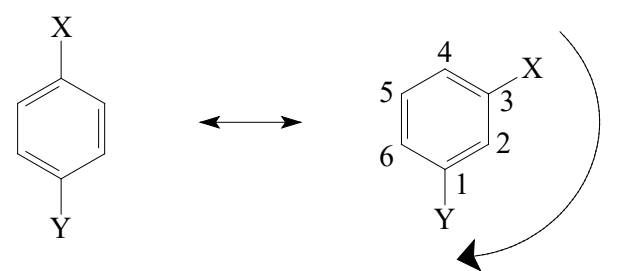

D

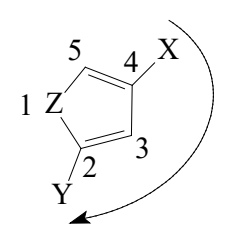

$4-\mathrm{X}-2-\mathrm{COOH}$
$E$

Scheme 3 
Again similarly the carbon 3 of the structure I could best be assumed as an ortho-carbon as shown in scheme 4.<smiles>[X]c1ccc([X])cc1</smiles>

G

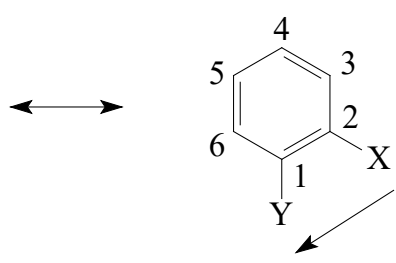

H

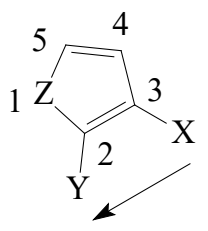

$3-\mathrm{X}-2-\mathrm{COOH}$

Scheme 4

In fact molecular orbital calculations and dipole moment data of 2-X-thiophene carboxylic acids suggested that the para, meta and ortho carbons of benzene correspond to 5, 4 and 3 carbons of the 5 membered heterocycle $[13,14]$. From the correlation of carbon-13 chemical shifts versus $1 \mathrm{H}$-proton chemical shifts, in which the striking parallelism of the resonance shifts of the benzene and five membered heterocycle nuclei, implies that the resonances of both nuclei respond in a parallel way to the local $\pi$-electron density on the carbon atom [15]. And as such five membered heterocycles with one or two heteroatoms are planar pentagons. They have sp2 hybridized carbon atoms. They possess significant aromatic character resulting from the lone pair of electrons of the hetero atom/s and the two pairs of carbon $\pi$ electrons.

\section{Examples:}

To start with, tables 1-4 show the $\mathrm{p} K_{\mathrm{a}}$ and Hammett substituent constants data of 5-X-2furoicacids, 5-X-2-pyrrole carboxylic acids, 5-X-2-thiophene carboxylic acids and 5-X-2tellurophen carboxylic acids respectively and figures 1-12 show the corresponding Hammett and Taft plots. 
5-X-2-furoic acids:

Below is the table 1 with the data of 5-X-2-furoic acids.

\begin{tabular}{|c|c|c|c|c|c|c|}
\hline \multicolumn{7}{|c|}{ Table 1: $\mathrm{p} K_{\mathrm{a}}$, Hammett $\sigma_{\mathrm{p}}, \sigma_{\mathrm{m}}$ and Taft $\sigma_{\text {ortho }}^{*}$ values of 5-X-2-furoicacids } \\
\hline \multirow{2}{*}{ S1. No. } & \multirow{2}{*}{$X$} & \multirow{2}{*}{$\mathrm{p} K_{\mathrm{a}}$} & \multicolumn{2}{|c|}{ Hammett } & \multirow{2}{*}{$\begin{array}{c}\text { Taft } \\
\sigma_{\text {ortho }}^{*}\end{array}$} & \multirow{2}{*}{ Literature for $\mathrm{p} K_{\mathrm{a}}$ values } \\
\hline & & & $\sigma_{\mathrm{p}}$ & $\sigma_{\mathrm{m}}$ & & \\
\hline 1 & $\mathrm{H}$ & 3.12 & 0.00 & 0.00 & 0.49 & https://en.wikipedia.org/wiki/2-Furoic_acid \\
\hline 2 & $\mathrm{NO}_{2}$ & 2.06 & 0.80 & 0.71 & 4.00 & $\begin{array}{l}\text { https://m.chemicalbook.com/ProductMSDSDetailCB01503 } \\
92 \text { EN.htm }\end{array}$ \\
\hline 3 & $\mathrm{Me}$ & 3.41 & -0.17 & -0.07 & 0.00 & $\begin{array}{l}\text { https://www.chemicalbook.com/ChemicalProductProperty } \\
\text { EN CB2262105.htm }\end{array}$ \\
\hline 4 & Et & 3.38 & -0.15 & -0.07 & -0.10 & $\begin{array}{l}\text { https://www.chemicalbook.com/ChemicalProductProperty } \\
\text { EN CB41117428.htm }\end{array}$ \\
\hline 5 & $\mathrm{Cl}$ & 2.84 & 0.23 & 0.37 & 2.96 & $\begin{array}{l}\text { https://www.chemicalbook.com/ChemicalProductProperty } \\
\text { EN CB51091079.htm }\end{array}$ \\
\hline 6 & $\mathrm{COOH}$ & 2.28 & 0.43 & 0.36 & 2.08 & https://en.wikipedia.org/wiki/2,5-Furandicarboxylic_acid \\
\hline 7 & $\mathrm{CF}_{3}$ & 2.44 & 0.54 & 0.43 & 2.55 & $\begin{array}{l}\text { https://m.chemicalbook.com/ChemicalProductProperty_EN } \\
\text { CB8506689.htm }\end{array}$ \\
\hline 8 & $\mathrm{CH}_{2} \mathrm{OH}$ & 3.11 & 0.08 & 0.08 & 0.55 & $\begin{array}{l}\text { https://www.chemicalbook.com/ChemicalProductProperty } \\
\text { EN CB7188710.htm }\end{array}$ \\
\hline
\end{tabular}

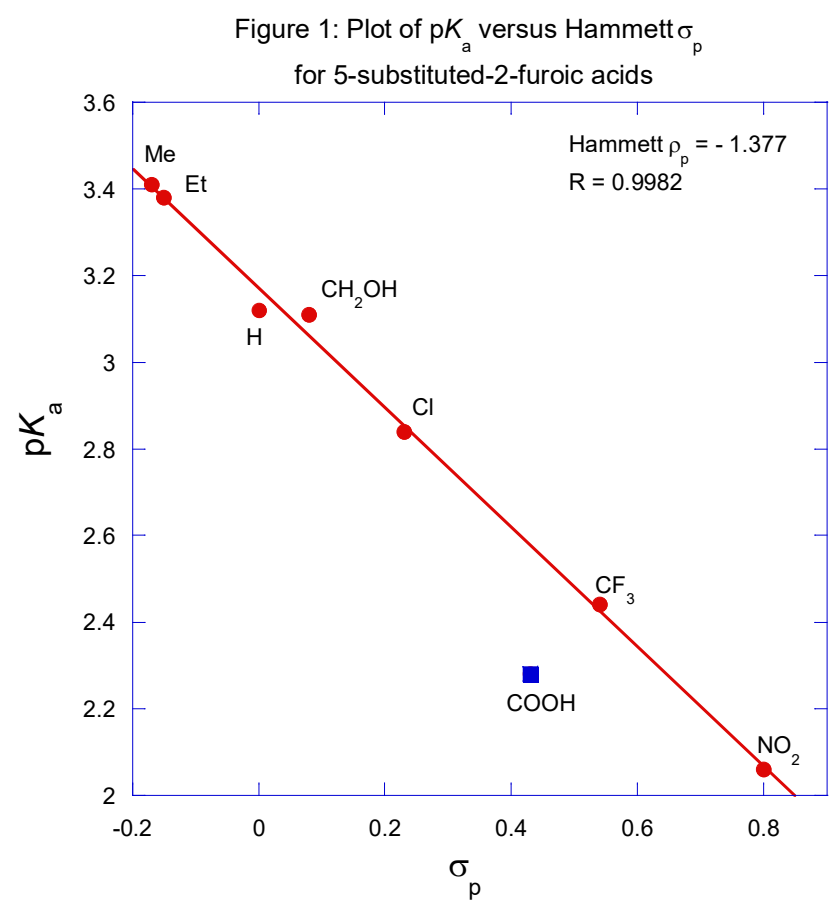



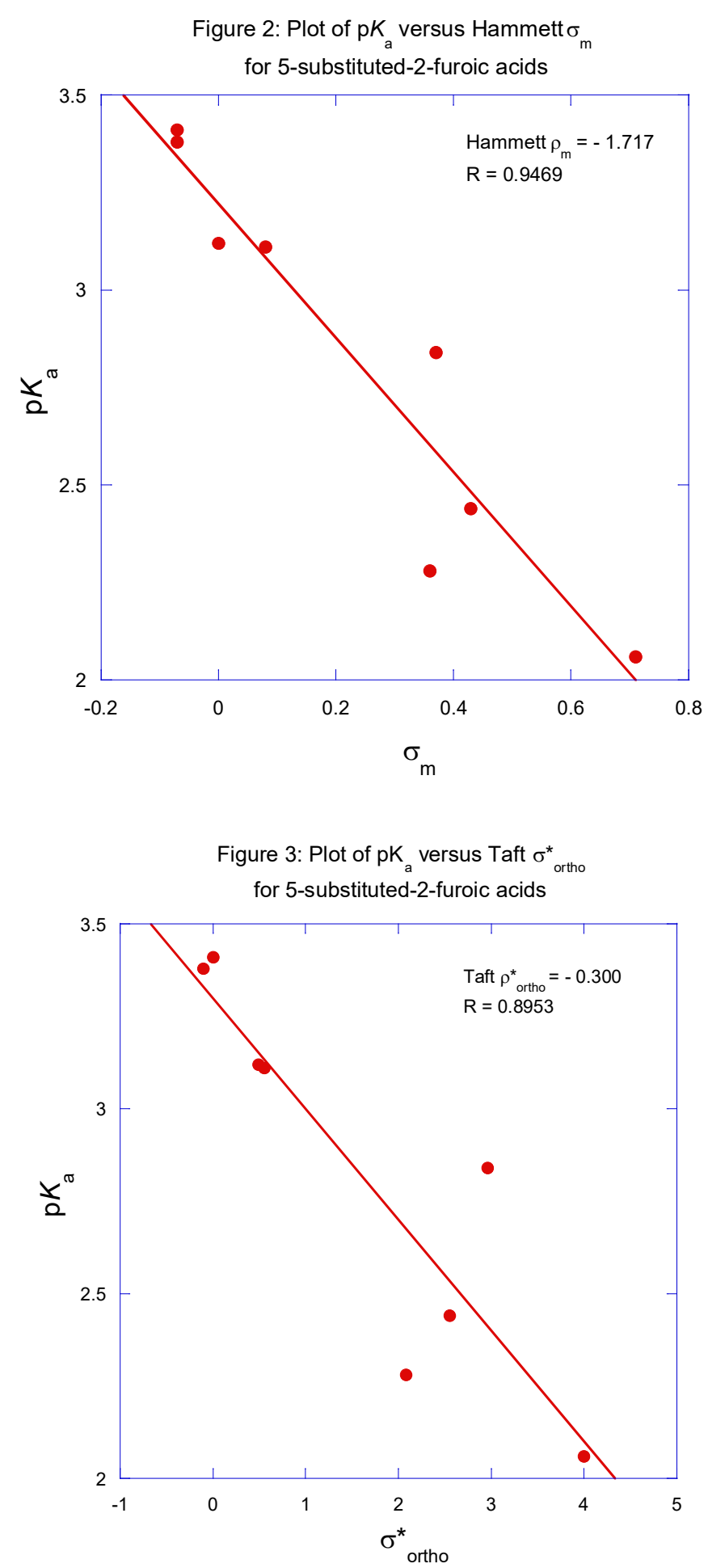

In the figures $1-3$, it is clear from the correlation coefficients, the $\mathrm{p} K_{\mathrm{a}}$ data of $5-\mathrm{X}-2$-furoic acids correlated well (Hammett $\left.\rho_{p}=-1.377, \mathrm{R}=0.9982\right)$ with Hammett $\sigma_{\mathrm{p}}$ values with a deviation of the lone - $\mathrm{COOH}$ substituent. This could be due to the week hydrogen bonding interaction as shown below in scheme 5 in one of the 2-furoic acid (trans) conformers between $\mathrm{H}$ of $-\mathrm{COOH}$ and $\mathrm{O}$ of the ring [16]. Therefore, good correlation of $\mathrm{p} K_{\mathrm{a}}$ data with 
para-substituent constants, the 5 position of the 2 -furoic acid is best assumed as paraposition.<smiles></smiles>

Scheme 5

The Hammett $\rho_{\mathrm{m}}$ is reported for $4-\mathrm{X}$-2-furoic acids as 1.40 with a correlation coefficient of 0.988 [10]. But to reproduce the plot here in this work, the journal Iowa State Coll. J. Sci. is not approachable.

\section{5-X-2-pyrrole carboxylic acids:}

Below is the table 2 with the data of 5-X-2-pyrrole carboxylic acids.

Table 2: $\mathrm{p} K_{\mathrm{a}}$, Hammett $\sigma_{\mathrm{p}}, \sigma_{\mathrm{m}}$ and Taft $\sigma_{\text {ortho }}^{*}$ values of 5-X-2-pyrrole carboxylic acids

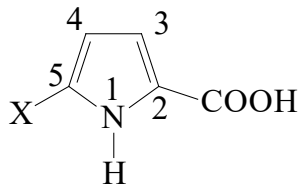

\begin{tabular}{|c|c|c|c|c|c|c|}
\hline \multirow{2}{*}{ S1. No. } & \multirow{2}{*}{$X$} & \multirow{2}{*}{$\mathrm{p} K \mathrm{a}$} & \multicolumn{2}{|c|}{ Hammett } & \multirow{2}{*}{$\begin{array}{c}\text { Taft } \\
\sigma_{\text {ortho }}^{*} \\
\end{array}$} & \multirow{2}{*}{ Literature for $\mathrm{p} K$ a values } \\
\hline & & & $\sigma_{p}$ & $\sigma_{\mathrm{m}}$ & & \\
\hline 1 & $\mathrm{H}$ & 4.50 & 0.00 & 0.00 & 0.49 & $\begin{array}{l}\text { https://www.chemicalbook.com/ChemicalProductProper } \\
\text { ty EN CB9414565.htm }\end{array}$ \\
\hline 2 & $\mathrm{Me}$ & 4.73 & -0.17 & -0.07 & 0.00 & $\begin{array}{l}\text { https://www.chemicalbook.com/ChemicalProductProper } \\
\text { ty EN CB2803461.htm }\end{array}$ \\
\hline 3 & $\mathrm{COOH}$ & 3.47 & 0.43 & 0.36 & 2.08 & $\begin{array}{l}\text { https://www.chemicalbook.com/ChemicalProductProper } \\
\text { ty EN CB02105716.htm }\end{array}$ \\
\hline 4 & $\mathrm{CF}_{3}$ & 3.63 & 0.54 & 0.43 & 2.55 & $\begin{array}{l}\text { https://www.chemicalbook.com/ChemicalProductProper } \\
\text { ty EN CB03172337.htm }\end{array}$ \\
\hline 5 & $\mathrm{C}_{6} \mathrm{H}_{5}$ & 4.45 & -0.01 & 0.06 & 0.60 & $\begin{array}{l}\text { https://m.chemicalbook.com/ProductChemicalProperties } \\
\text { CB1447413_EN.htm }\end{array}$ \\
\hline 6 & $\mathrm{NO}_{2}$ & 3.22 & 0.80 & 0.71 & 4.00 & \multirow{3}{*}{$\begin{array}{l}\text { pKa values are from F. Fringuelli, G. Marino and } \\
\text { G. Savelli, Tetrahedron, vol. } 25 \text {, page } 5815,1969\end{array}$} \\
\hline 7 & $\mathrm{Br}$ & 4.17 & 0.23 & 0.39 & 2.84 & \\
\hline 8 & $\mathrm{Cl}$ & 4.32 & 0.23 & 0.37 & 2.96 & \\
\hline
\end{tabular}




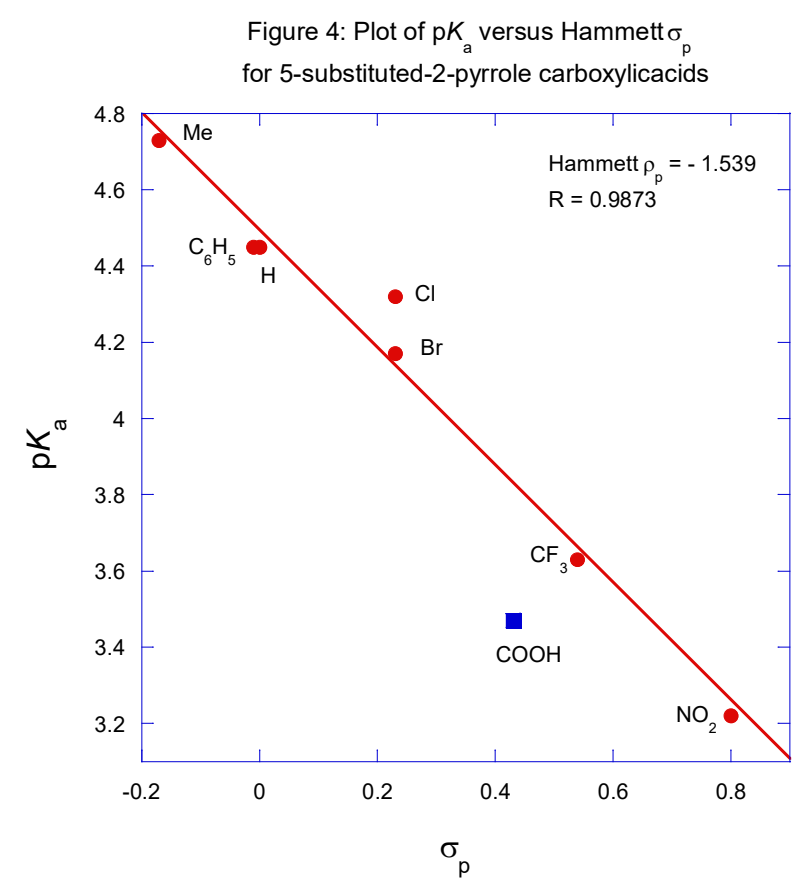

Figure 5: Plot of $p K_{a}$ versus Hammett $\sigma_{m}$ for 5-substituted-2-pyrrole carboxylicacids

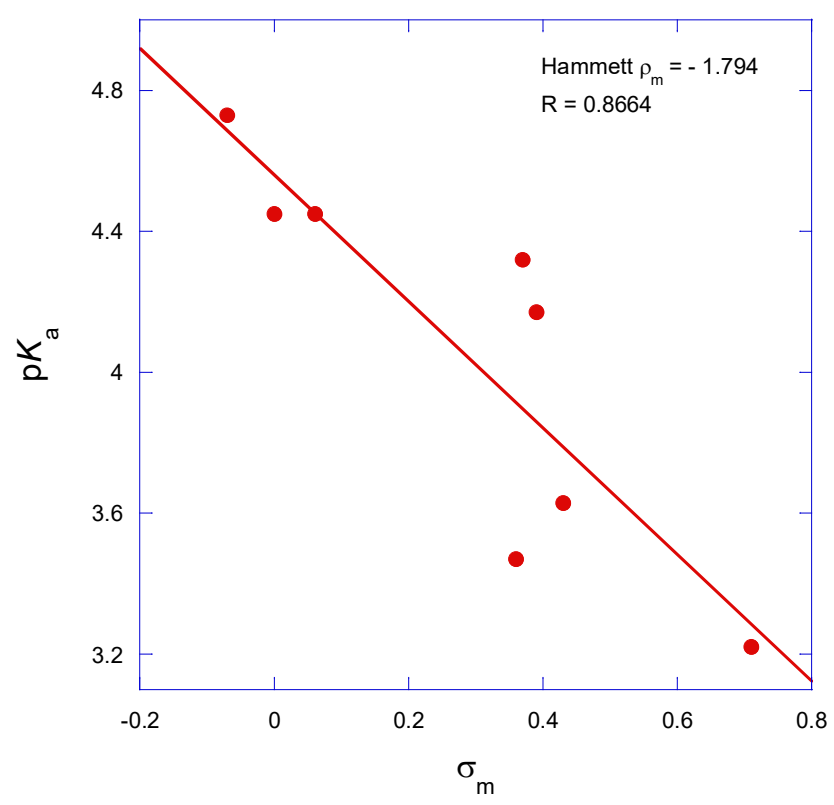




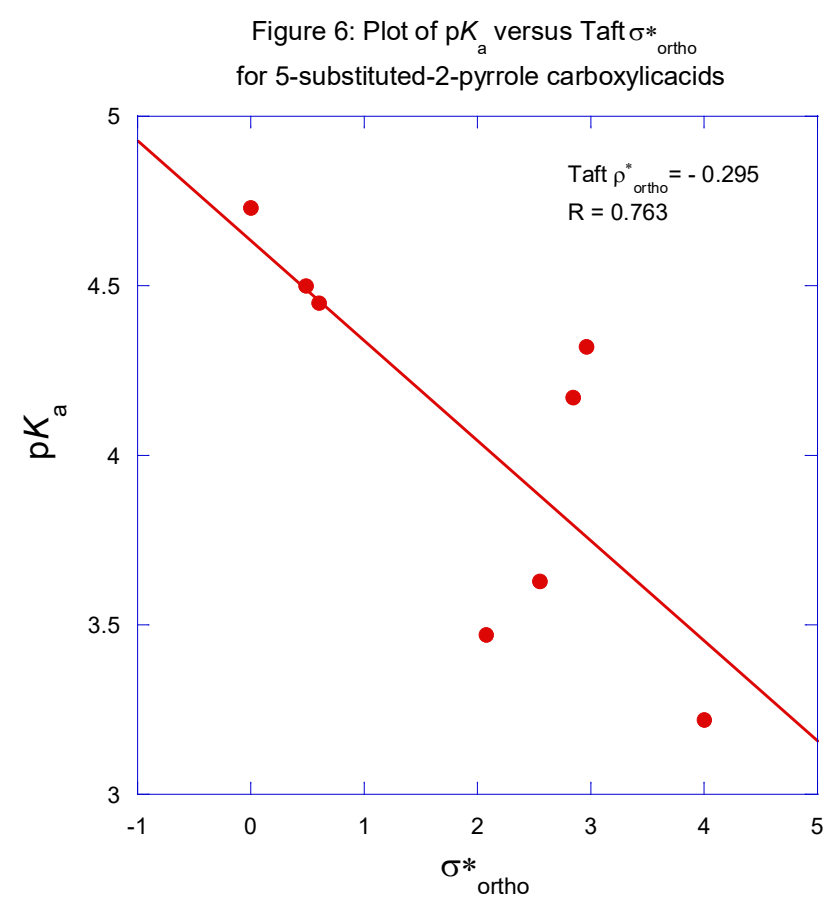

In the figures $4-6$, it is clear from the correlation coefficients, the $\mathrm{p} K_{\mathrm{a}}$ data of 5-X-2-pyrrole carboxylic acids correlated well (Hammett $\left.\rho_{p}=-1.539, R=0.9873\right)$ with Hammett $\sigma_{p}$ values with a deviation of again the lone $-\mathrm{COOH}$ substituent. This could be due to two types of intramolecular hydrogen bonding interaction as shown below in scheme 6 [17]. Therefore the 5 position of the 2-pyrrole carboxylic acid is best assumed as para-position.<smiles></smiles><smiles>Cn1c(C(=O)O)ccc1C(=O)O</smiles>

Scheme 6 
5-X-2-thiophene carboxylic acids:

Below is the table 3 with the data of 5-X-2- thiophene carboxylic acids.

Table 3: $\mathrm{p} K_{\mathrm{a}}$, Hammett $\sigma_{\mathrm{p}}, \sigma_{\mathrm{m}}$ and Taft $\sigma_{\text {ortho }}^{*}$ values of 5-X-2-thiophene carboxylic acids

\begin{tabular}{|c|c|c|c|c|c|c|}
\hline \multirow{2}{*}{ Sl. No. } & \multirow{2}{*}{$\mathrm{X}$} & \multirow{2}{*}{$\mathrm{p} K_{\mathrm{a}}$} & \multicolumn{2}{|c|}{ Hammett } & \multirow{2}{*}{$\begin{array}{c}\text { Taft } \\
\sigma_{\text {ortho }}^{*}\end{array}$} & \multirow{2}{*}{ Literature for $\mathrm{p} K_{\mathrm{a}}$ values } \\
\hline & & & $\sigma_{p}$ & $\sigma_{\mathrm{m}}$ & & \\
\hline 1 & $\mathrm{H}$ & 3.49 & 0.00 & 0.00 & 0.49 & $\begin{array}{l}\text { https://www.chemicalbook.com/ProductChemicalProper } \\
\text { tiescb1778926 EN.htm }\end{array}$ \\
\hline 2 & $\mathrm{NO}_{2}$ & 2.69 & 0.80 & 0.71 & 4.00 & $\begin{array}{l}\text { https://www.chemicalbook.com/ChemicalProductProper } \\
\text { ty EN CB2197443.htm }\end{array}$ \\
\hline 3 & $\mathrm{Me}$ & 3.71 & -0.17 & -0.07 & 0.00 & $\begin{array}{l}\text { https://www.chemicalbook.com/ChemicalProductProper } \\
\text { ty EN CB3183843.htm }\end{array}$ \\
\hline 4 & $\mathrm{Cl}$ & 3.32 & 0.23 & 0.37 & 2.96 & $\begin{array}{l}\text { https://www.chemicalbook.com/ChemicalProductProper } \\
\text { ty EN CB3189269.htm }\end{array}$ \\
\hline 5 & $\mathrm{COOH}$ & 2.76 & 0.43 & 0.36 & 2.08 & $\begin{array}{l}\text { https://www.chemicalbook.com/ChemicalProductProper } \\
\text { ty EN CB9224515.htm }\end{array}$ \\
\hline 6 & $\mathrm{MeO}$ & 3.80 & -0.27 & 0.12 & 1.81 & \multirow{3}{*}{$\begin{array}{l}\mathrm{p} K_{\mathrm{a}} \text { values are from Anthony R. Butler, J. Chem. } \\
\text { Soc. (B), page } 867,1970\end{array}$} \\
\hline 7 & $\mathrm{Et}$ & 3.70 & -0.15 & -0.07 & -0.10 & \\
\hline 8 & $\mathrm{Br}$ & 3.19 & 0.23 & 0.39 & 2.84 & \\
\hline
\end{tabular}

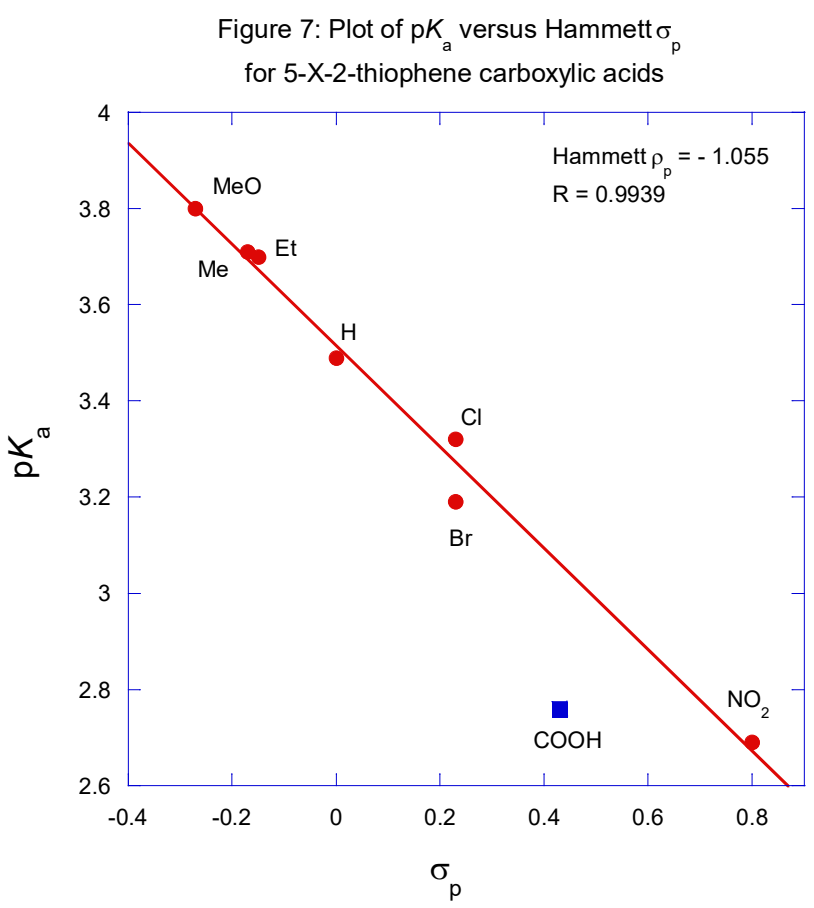



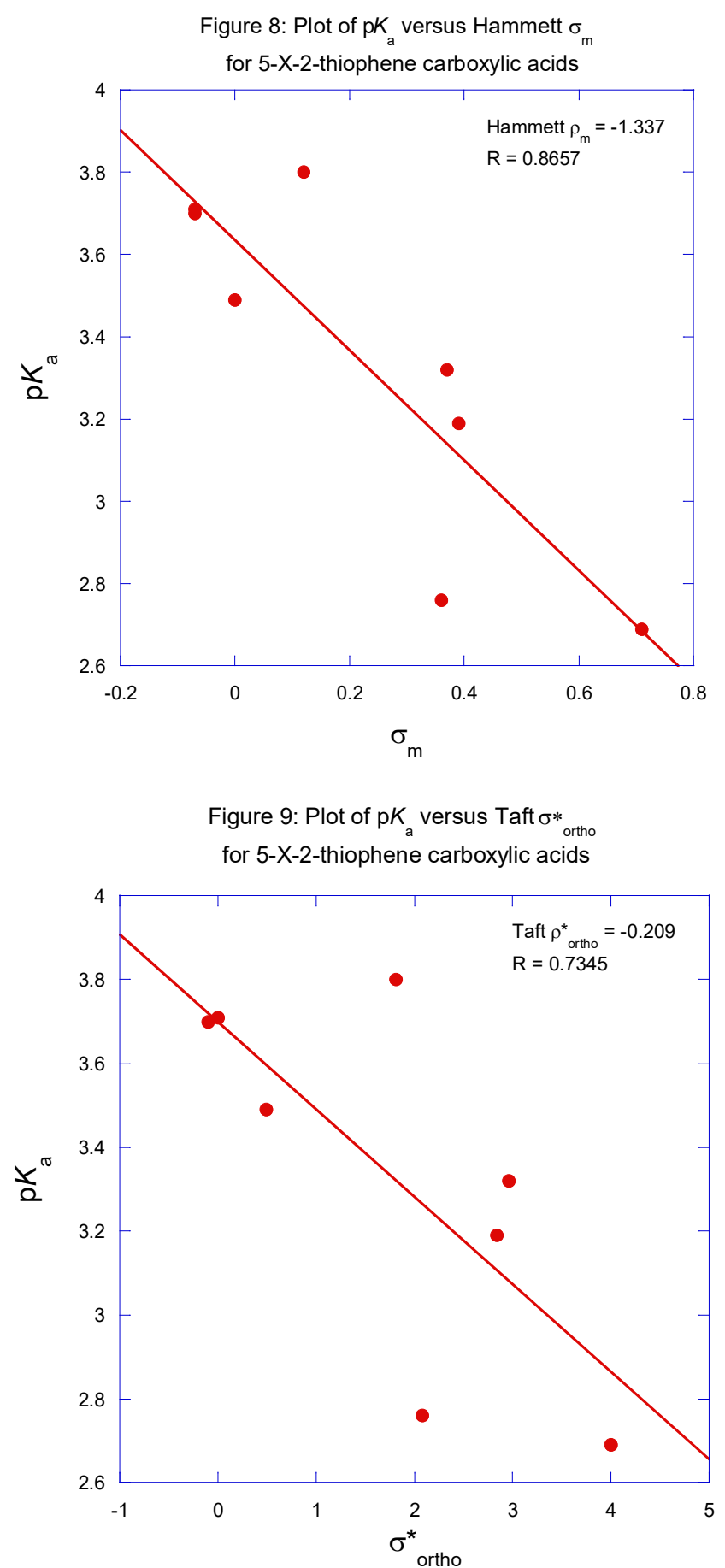

In the figures 7-9, it is clear from the correlation coefficients, the $\mathrm{p} K_{\mathrm{a}}$ data of $5-\mathrm{X}-2$-thiophene carboxylic acids correlated well (Hammett $\left.\rho_{p}=-1.055, \mathrm{R}=0.9939\right)$ with Hammett $\sigma_{\mathrm{p}}$ values with a deviation of again the lone $-\mathrm{COOH}$ substituent. This could be due to the week intramolecular hydrogen bonding interaction of $\mathrm{H}$ of $\mathrm{COOH}$ with $\mathrm{S}$ of thiophene ring as shown below in scheme 7 . It is revealed in some protein interactions that though sulfur is a moderately good H-bond donor but also a week H-bond acceptor [18]. Therefore, again the 5 position of the 2-thiophene carboxylic acid is best assumed as para-position. 
<smiles></smiles>

Scheme 7

5-X-2-tellurophen carboxylic acids:

Below is the table 4 with the data of 5-X-2-tellurophen carboxylic acids.

Table 4: $\mathrm{p} K_{\mathrm{a}}$, Hammett $\sigma_{\mathrm{p}}, \sigma_{\mathrm{m}}$ and Taft $\sigma_{\text {ortho }}^{*}$ values of 5-X-2-tellurophen carboxylic acids

\begin{tabular}{|c|c|c|c|c|c|c|}
\hline \multirow{2}{*}{ Sl. No. } & \multirow{2}{*}{$X$} & \multirow{2}{*}{$\mathrm{p} K_{\mathrm{a}}$} & \multicolumn{2}{|c|}{ Hammett } & \multirow{2}{*}{$\begin{array}{c}\text { Taft } \\
\sigma_{\text {ortho }}^{*}\end{array}$} & \multirow{2}{*}{$\begin{array}{l}\text { Literature for } \mathrm{p} K_{\mathrm{a}} \\
\text { values }\end{array}$} \\
\hline & & & $\sigma_{p}$ & $\sigma_{\mathrm{m}}$ & & \\
\hline 1 & $\mathrm{H}$ & 3.97 & 0.00 & 0.00 & 0.49 & \multirow{5}{*}{$\begin{array}{c}\mathrm{p} K_{\mathrm{a}} \text { values are from F. } \\
\text { Fringuelli, G. Marino," and A. } \\
\text { Taticchi, J. Chem. Soc., } \\
\text { perkin II, page 1738, } 1972\end{array}$} \\
\hline 2 & $\mathrm{Me}$ & 4.16 & -0.17 & -0.07 & 0.00 & \\
\hline 3 & Ac & 3.36 & 0.50 & 0.38 & 1.65 & \\
\hline 4 & $\mathrm{COOH}$ & 3.11 & 0.43 & 0.36 & 2.08 & \\
\hline 5 & $\mathrm{COO}^{-}$ & 4.24 & 0.00 & -0.10 & -1.06 & \\
\hline
\end{tabular}

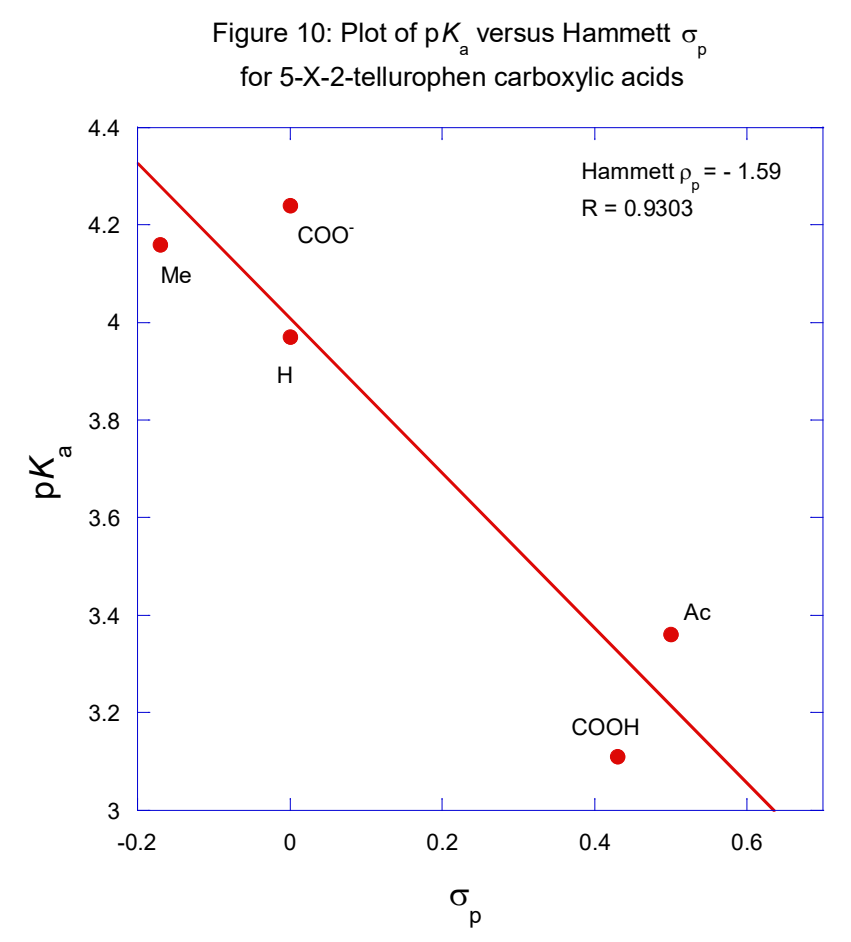



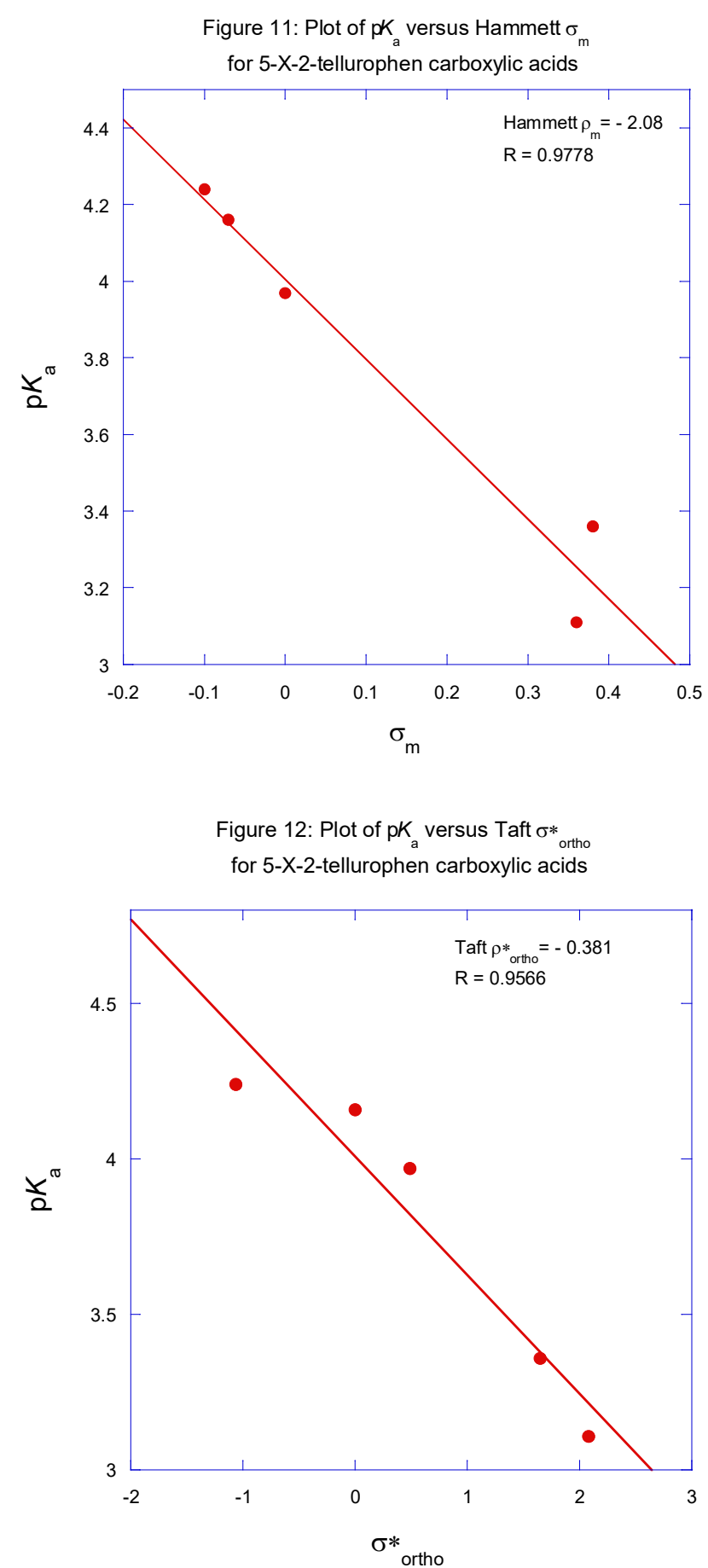

In the figures $10-12$, it is clear from the correlation coefficients $0.9303,0.9778$ and 0.9566 the $\mathrm{p} K_{\mathrm{a}}$ data of 5-X-2-tellurophen carboxylic acids did not correlate well with any of the $\sigma$ values. And certainly, the correlation with $\sigma_{\mathrm{p}}$ values is very poor $(\mathrm{R}=0.9303)$. However, though the correlation coefficient of $\mathrm{p} K_{\mathrm{a}}$ values versus $\sigma_{\text {ortho }}^{*}$ is less than that of with $\sigma_{\mathrm{m}}$ the points in figure 12 are evenly distributed on either side of the line of fit. Taking this argument in to confidence the correlation of $\mathrm{p} K_{\mathrm{a}}$ values with $\sigma_{\text {ortho }}^{*}$ needs a different explanation which is as follows: In benzene if we observe the substituent ortho to the functional group is in 
principle separated by a double bond again keeping in view of the statistical weight of the dynamic equilibrium of benzene or it simply needs a pair of $\pi$ electrons (Scheme $4, \mathbf{H}$ ). In five membered ring system of 5-X-2-tellurophen carboxylic acid that lone $\pi$ electron pair can be seen with tellurium. As tellurium has a maximum polarizability and bigger in size than either sulfur or oxygen [19] the substituent effect more easily be transmitted from the substituent to the functional group via tellurium rather than $\pi$ electron pair of the five membered ring as shown below in scheme 8 .

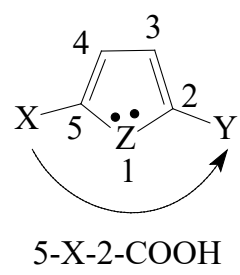

Scheme 8

\section{4-X-2-pyrrole carboxylic acids:}

Below is the Table 5 with $\mathrm{p} K_{\mathrm{a}}$, Hammett $\sigma_{\mathrm{p}}, \sigma_{\mathrm{m}}$ and Taft $\sigma_{\text {ortho }}^{*}$ values of 4 -X-2-pyrrole carboxylic acids

Table 5: $\mathrm{p} K_{\mathrm{a}}$, Hammett $\sigma_{\mathrm{p}}, \sigma_{\mathrm{m}}$ and Taft $\sigma_{\text {ortho }}^{*}$ values of 4-X-2-pyrrole carboxylic acids

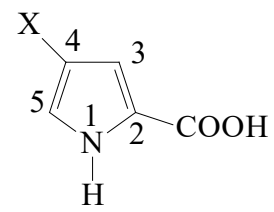

\begin{tabular}{|c|c|c|c|c|c|c|}
\hline \multirow{2}{*}{ Sl. No. } & \multirow{2}{*}{$\mathrm{X}$} & \multirow{2}{*}{$\mathrm{p} K_{\mathrm{a}}$} & \multicolumn{2}{|c|}{ Hammett } & \multirow{2}{*}{$\begin{array}{c}\text { Taft } \\
\sigma_{\text {ortho }}^{*}\end{array}$} & \multirow{2}{*}{ Literature for $\mathrm{p} K_{\mathrm{a}}$ values } \\
\hline & & & $\sigma_{p}$ & $\sigma_{\mathrm{m}}$ & & \\
\hline 1 & $\mathrm{H}$ & 4.50 & 0.00 & 0.00 & 0.49 & \multirow{5}{*}{$\begin{array}{l}\mathrm{p} K_{\mathrm{a}} \text { values are from } \mathrm{F} . \\
\text { Fringuelli, G. Marino and G. } \\
\text { Savelli, Tetrahedron, vol. 25, } \\
\text { page } 5815\end{array}$} \\
\hline 2 & $\mathrm{Me}$ & 4.60 & -0.17 & -0.07 & 0.00 & \\
\hline 3 & $\mathrm{NO}_{2}$ & 3.37 & 0.80 & 0.71 & 4.00 & \\
\hline 4 & $\mathrm{Br}$ & 4.06 & 0.23 & 0.39 & 2.84 & \\
\hline 5 & $\mathrm{Cl}$ & 4.07 & 0.23 & 0.37 & 2.96 & \\
\hline
\end{tabular}


Figure 13: Plot of $p K_{a}$ versus Hammett $\sigma_{p}$ for 4-X-2-pyrrole carboxylic acids

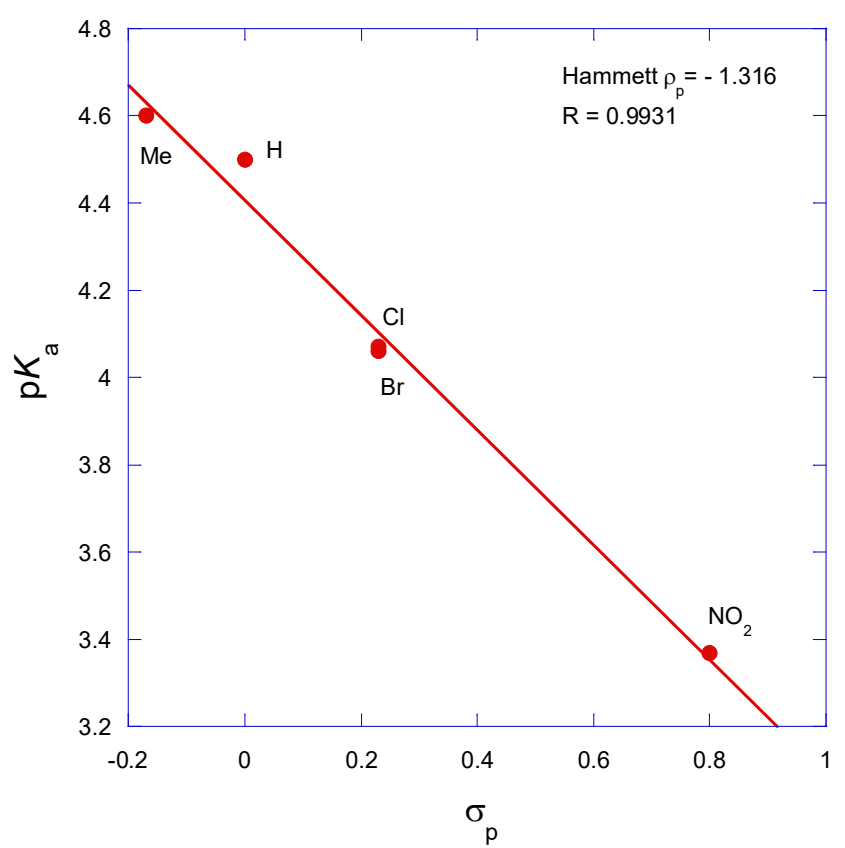

Figure 14: Plot of $\mathrm{pK} \mathrm{a}_{\mathrm{a}}$ versus Hammett $\sigma_{\mathrm{m}}$

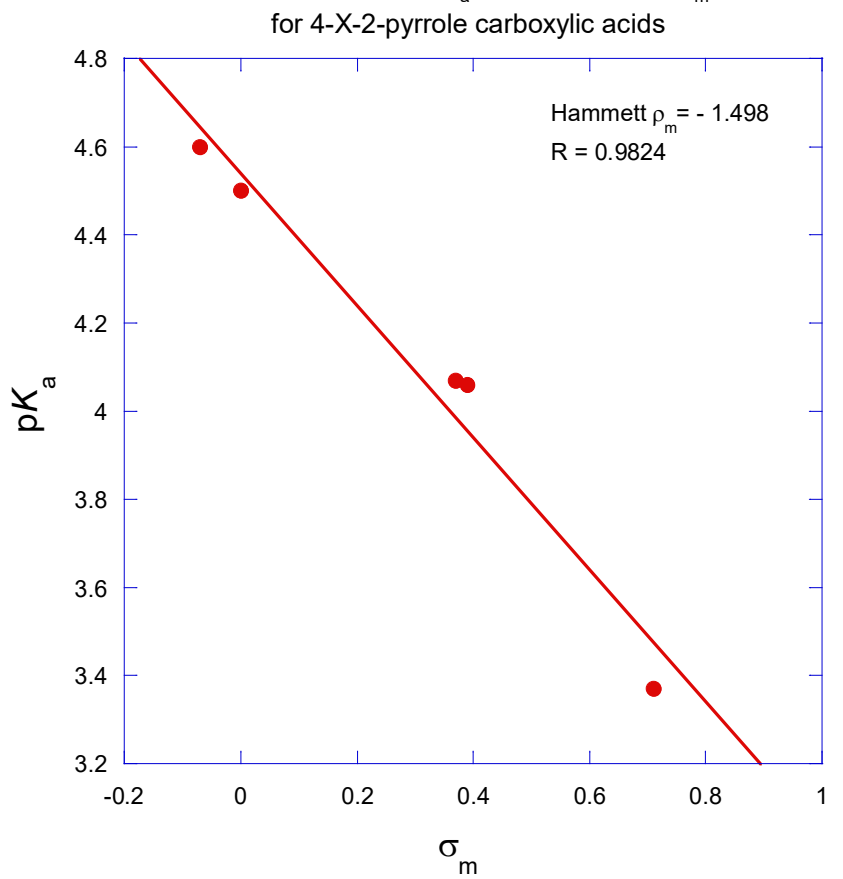




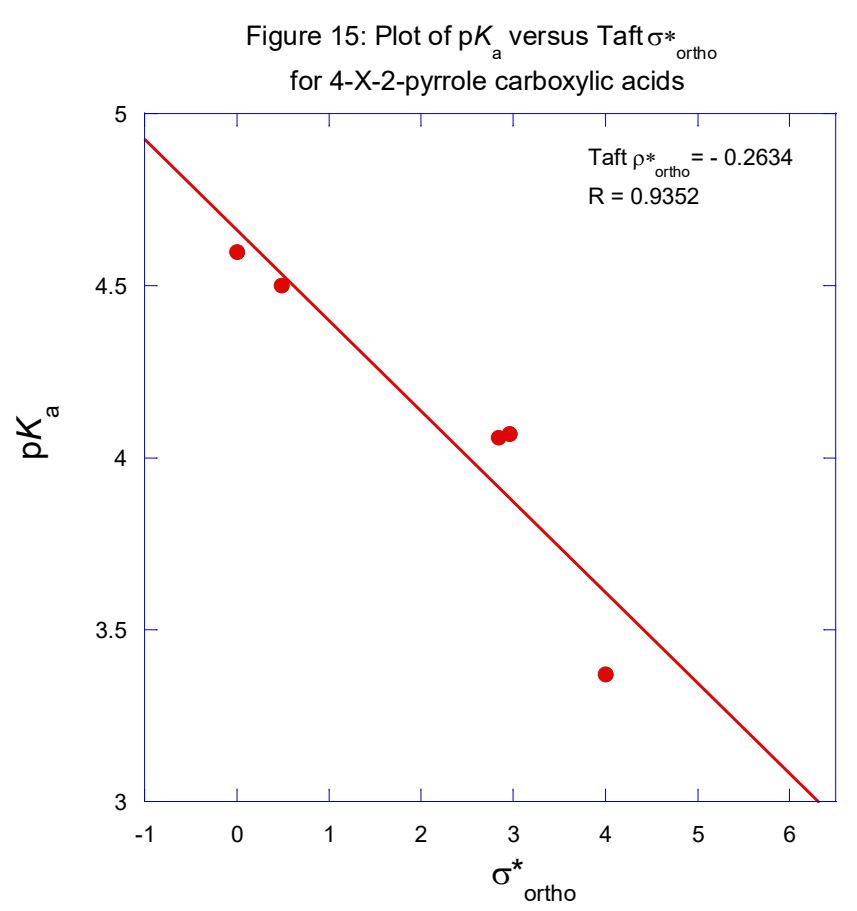

In figures $13-15$ it is noteworthy to see that $\mathrm{p} K$ a values of 4-X-2-pyrrole carboxylic acids correlate well with both $\sigma_{\mathrm{p}}$ and $\sigma_{\mathrm{m}}$ substituent constants. This is best visualized in the scheme 9. The transmission of substituent effect from $\mathrm{X}$ to $\mathrm{COOH}$ can take place in two directions one via carbon 5 and ring nitrogen and the other via carbon 3 as shown in scheme 9. If $\mathrm{X}$ behaves as a para-substituent, what it needs is a pair of two double bonds (see structure $\mathbf{B}$ of scheme 2) or a double bond and a pair of $\pi$ electrons or a pair of non-bonded electrons. A pair of non-bonded electrons is from nitrogen.

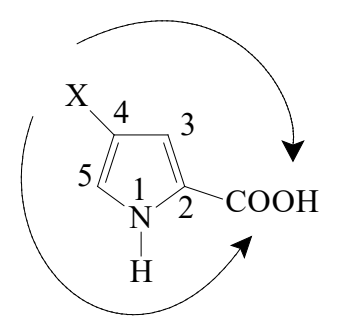

Scheme 9 


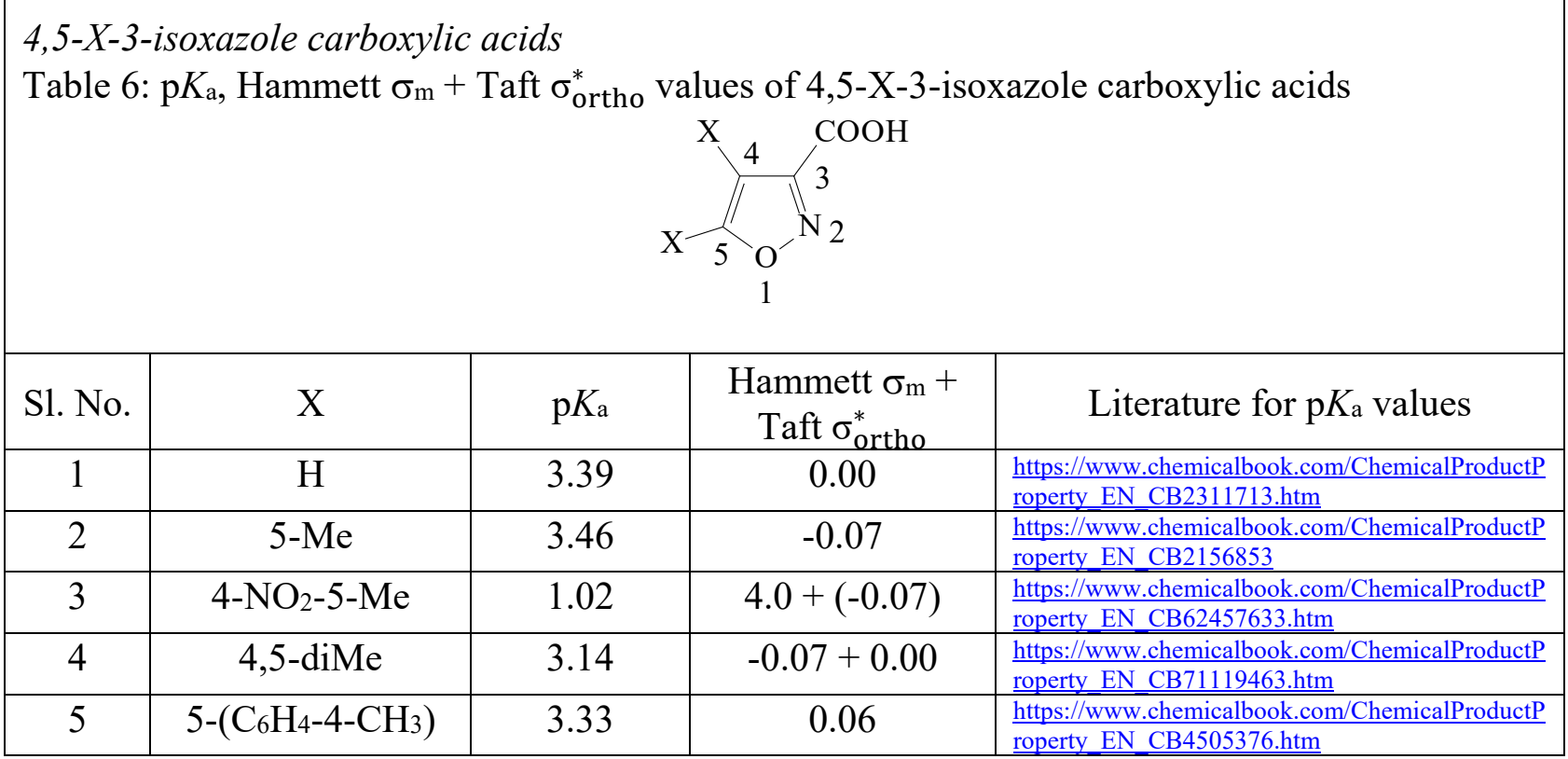

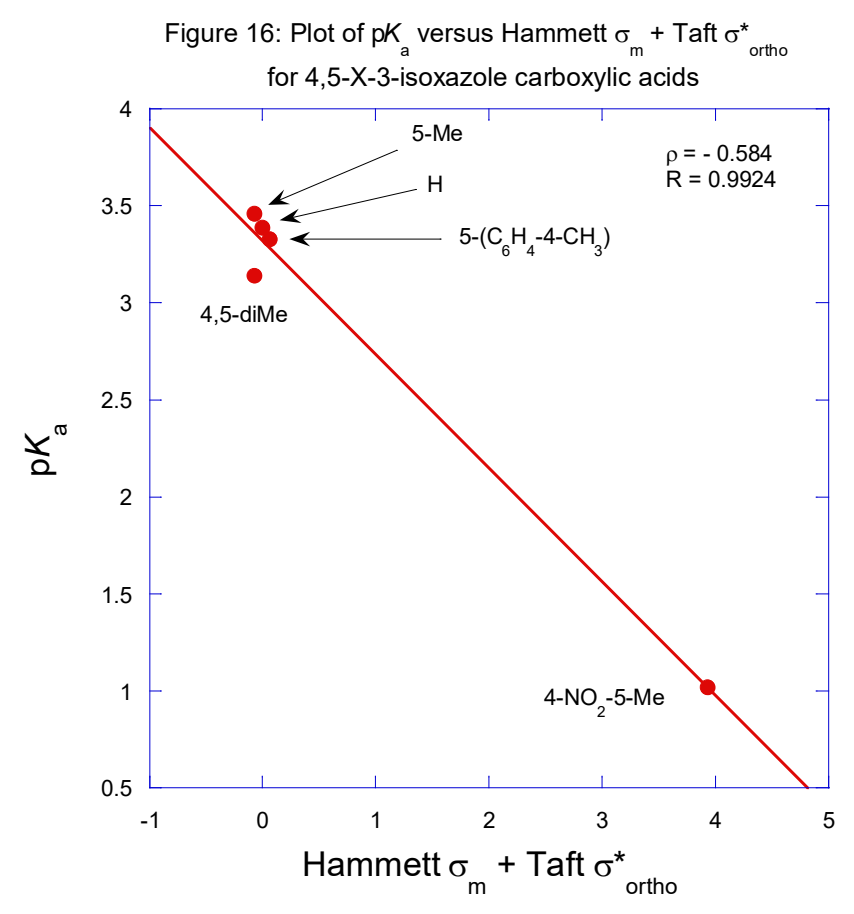

$\mathrm{p} K_{\mathrm{a}}$ values of 4,5-substituted-3-isoxazole carboxylic acids correlated well with (Hammett $\sigma_{\mathrm{m}}$ $+$

+ Taft $\sigma_{\text {ortho }}^{*}$ ) (Table 6, figure 16) which indicates that the carbon 4 and carbon 5 of 3isoxazole carboxylic acid just resemble as ortho and meta substituents respectively to $\mathrm{COOH}$. 
3,5-X-4-isoxazole carboxylic acids:

\begin{tabular}{|c|c|c|c|c|}
\hline S1. No. & $X$ & $\mathrm{p} K_{\mathrm{a}}$ & $\begin{array}{c}\text { Taft } \\
\sigma_{\text {orth }}^{*}\end{array}$ & Literature for $\mathrm{p} K_{\mathrm{a}}$ values \\
\hline 1 & $3-\mathrm{Me}$ & 2.90 & 0.00 & $\begin{array}{l}\text { https://www.chemicalbook.com/ChemicalProductPP } \\
\text { roperty EN CB5332030.htm }\end{array}$ \\
\hline 2 & $5-\mathrm{Me}$ & 2.85 & 0.00 & $\begin{array}{l}\text { https:///www.chemicalbook.com/ChemicalProductP } \\
\text { roperty EN CB8342928.htm }\end{array}$ \\
\hline 3 & 5 -Et & 2.81 & -0.10 & $\begin{array}{l}\text { https://www.chemicalbook.com/ChemicalProductPP } \\
\text { roperty EN CB4320960.htm }\end{array}$ \\
\hline 4 & 3-Br-5-Me & 1.53 & $2.84+0.00$ & $\begin{array}{l}\text { https:///www.chemicalbook.com/ChemicalProductP } \\
\text { roperty_EN_CB51275509.htm }\end{array}$ \\
\hline 5 & $5-\mathrm{NH}_{2}-3-\mathrm{Me}$ & 3.57 & $0.62+0.00$ & $\begin{array}{l}\text { https://www.chemicalbook.com/ChemicalProductPP } \\
\text { roperty EN CB0511575.htm }\end{array}$ \\
\hline
\end{tabular}

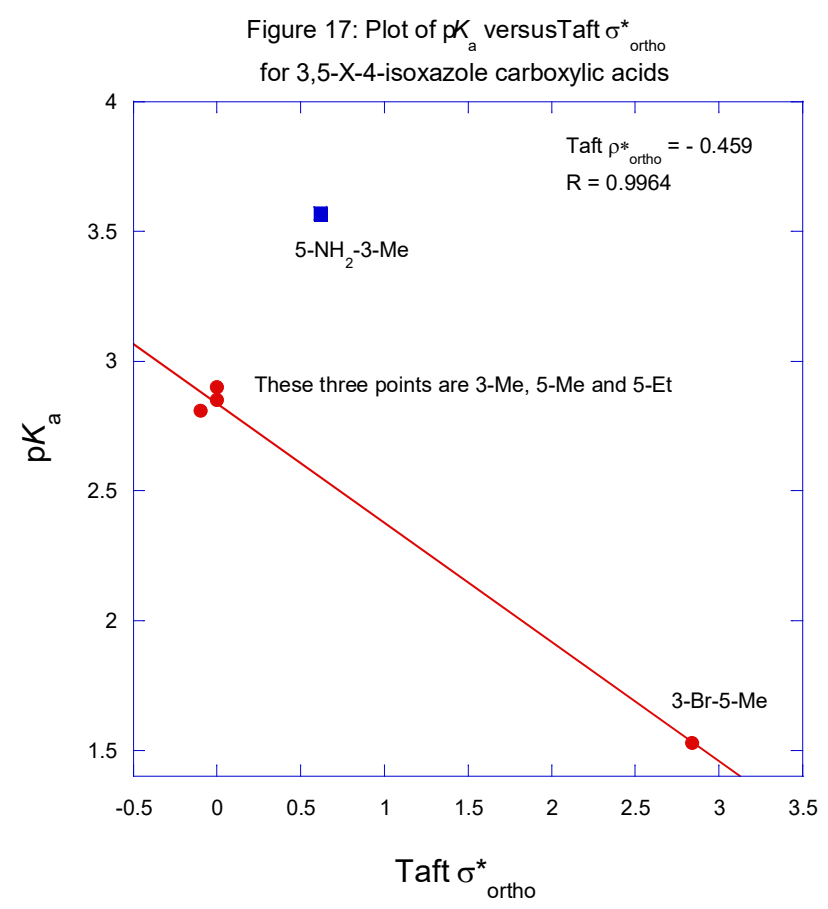

In 3,5-X-4-isoxazole carboxylic acids, the substituent $\mathrm{X}$ on either side of the functional group

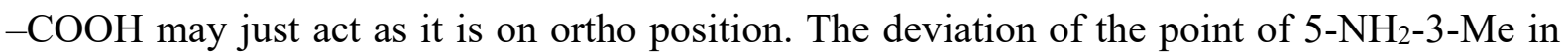
the correlation of $\mathrm{p} K_{\mathrm{a}}$ values with Taft $\sigma_{\text {ortho }}^{*}$ of 3,5-X-4-isoxazole carboxylic acid may be due to the formation of a zwitterion or two types of intramolecular H-bonding as shown in scheme 10 below. 

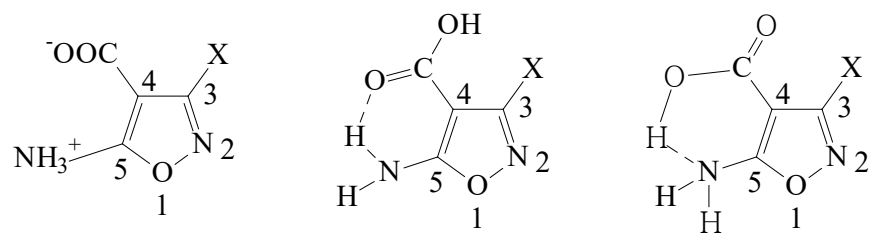

Scheme 10

\section{5-X-3-pyrazole carboxylic acids}

Table 8: $\mathrm{p} K_{\mathrm{a}}$, Hammett $\sigma_{\mathrm{p}}, \sigma_{\mathrm{m}}$ and $\sigma^{*}$ ortho values of 5-X-3-pyrazole carboxylic acids<smiles>[X]c1cc(C(=O)O)n[nH]1</smiles>

\begin{tabular}{|c|c|c|c|c|c|c|}
\hline \multirow{2}{*}{ Sl. No. } & \multirow{2}{*}{$\mathrm{X}$} & \multirow{2}{*}{$\mathrm{p} K_{\mathrm{a}}$} & \multicolumn{2}{|c|}{ Hammett } & \multirow{2}{*}{$\begin{array}{c}\text { Taft } \\
\sigma^{*} \text { ortho }\end{array}$} & \multirow{2}{*}{ Literature for $\mathrm{p} K_{\mathrm{a}}$ values } \\
\hline & & & $\sigma_{\mathrm{p}}$ & $\sigma_{\mathrm{m}}$ & & \\
\hline 1 & $\mathrm{H}$ & 3.98 & 0.00 & 0.00 & 0.49 & $\begin{array}{l}\text { https://www.chemicalbook.com/ProductList_en.asp } \\
\text { x? } 2 \text { kwd=3-pyrazolecarboxylic\%20acid }\end{array}$ \\
\hline 2 & $\mathrm{Me}$ & 4.04 & -0.17 & -0.07 & 0.00 & $\begin{array}{l}\text { D. D. Perrin, B. Dempsey and E. P. Serjeant, pKa } \\
\text { prediction of organic acids and bases, Springer } \\
\text { Science \& Business media, 1981, page } 85\end{array}$ \\
\hline 3 & $\mathrm{NO}_{2}$ & 3.22 & 0.80 & 0.71 & 4.00 & $\begin{array}{l}\text { https://www.chemicalbook.com/ChemicalProductPr } \\
\text { operty EN CB0223469.htm }\end{array}$ \\
\hline 4 & $\mathrm{Br}$ & 3.59 & 0.23 & 0.39 & 2.84 & $\begin{array}{l}\text { https://m.chemicalbook.com/ChemicalProductPrope } \\
\text { rty EN CB82594026.htm }\end{array}$ \\
\hline 5 & $\mathrm{Cl}$ & 3.61 & 0.23 & 0.37 & 2.96 & $\begin{array}{l}\text { https://www.chemicalbook.com/ChemicalProductPr } \\
\text { operty EN CB91501525.htm }\end{array}$ \\
\hline
\end{tabular}

Figure 18: Plot of $\mathrm{pK}$ a versus Hammett $\sigma_{\mathrm{p}}$ for 5-X-3-pyrazole carboxylic acids

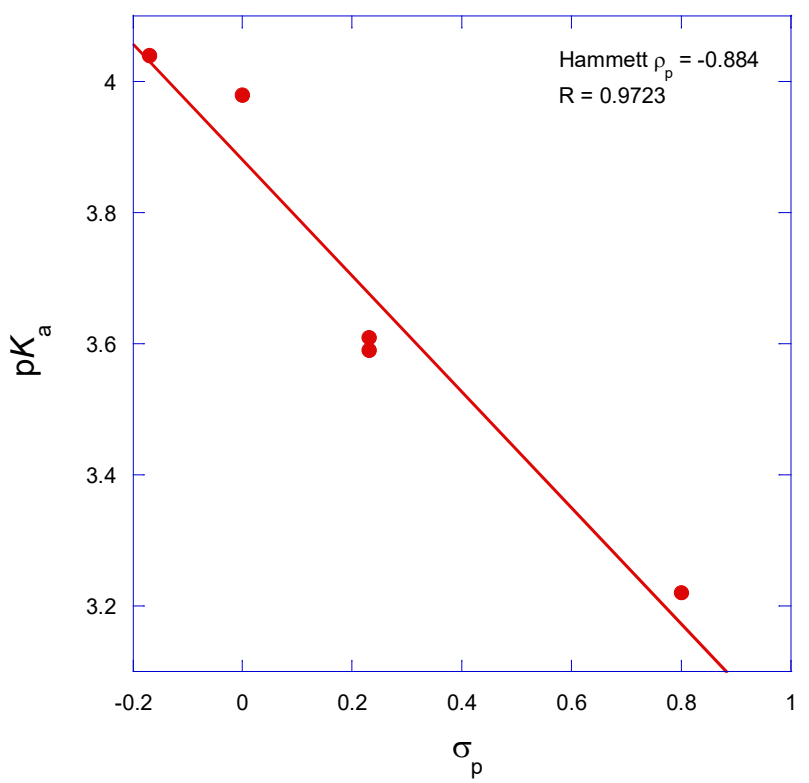



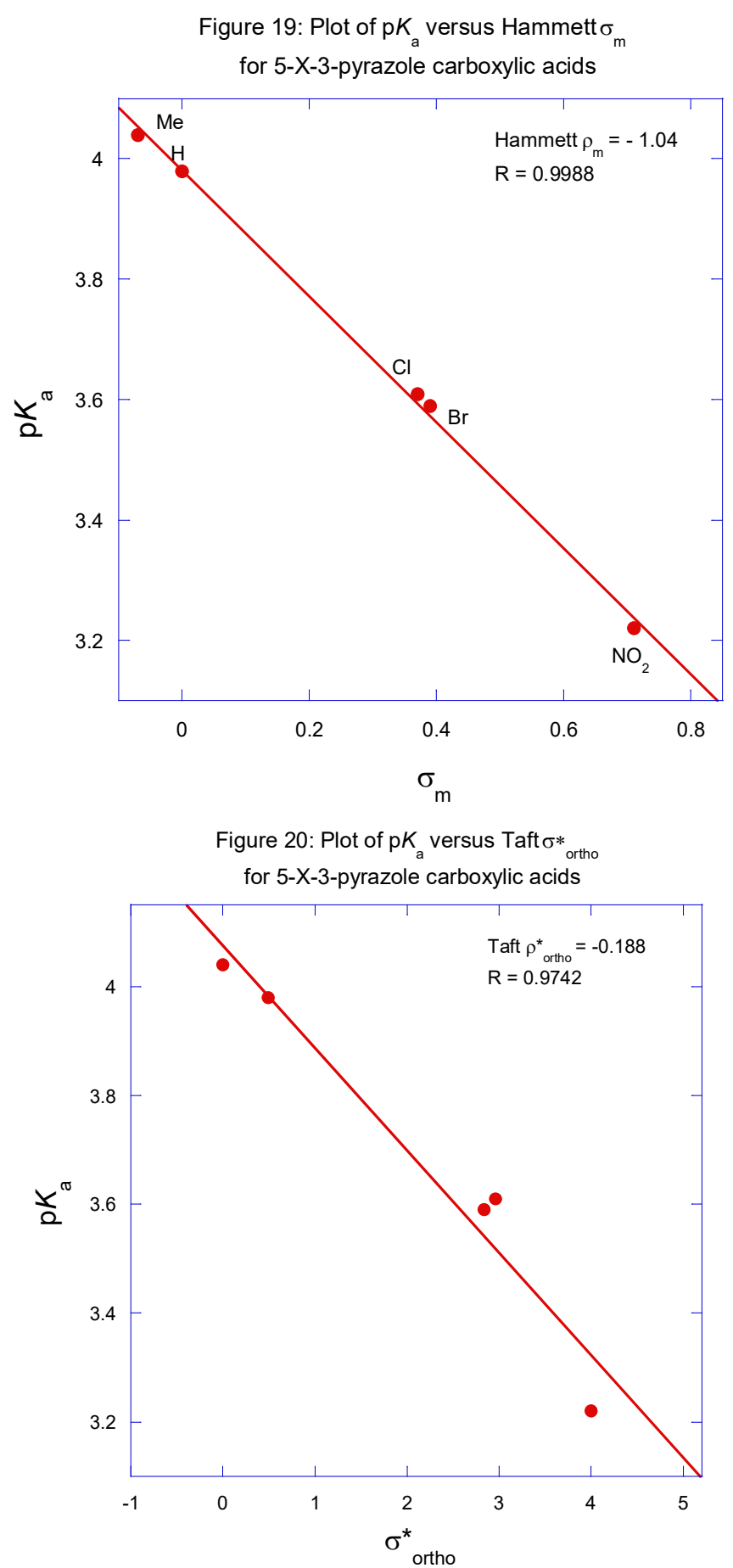

In the figures $18-20$, it is clear from the correlation coefficients, the $\mathrm{p} K_{\mathrm{a}}$ data of $5-\mathrm{X}-3-$ pyrazole carboxylic acids correlated well (Hammett $\rho_{\mathrm{m}}=-1.04, \mathrm{R}=0.9988$ ) with Hammett $\sigma_{\mathrm{m}}$ values. Therefore the 5 position of the 3-pyrazole carboxylic acid is best assumed as metaposition. 
1-Me-4/5-X-3-pyrazole carboxylic acids:

Table 9: $\mathrm{p} K_{\mathrm{a}}$, Hammett $\sigma_{\mathrm{m}}$ values of 1-Me-4/5-X-3-pyrazole carboxylic acids<smiles>[X]c1c(C(=O)O)nn(C)c1[X]</smiles>

\begin{tabular}{|c|c|c|c|c|}
\hline Sl. No. & $\mathrm{X}$ & $\mathrm{p} K_{\mathrm{a}}$ & $\begin{array}{c}\text { Hammett } \\
\sigma_{\mathrm{m}}\end{array}$ & Literature for $\mathrm{p} K \mathrm{a}$ values \\
\hline 1 & 4-Me & 3.82 & 0.00 & $\begin{array}{l}\text { https://www.chemicalbook.com/ChemicalProductProperty_EN } \\
\text { CB42510213.htm }\end{array}$ \\
\hline 2 & $5-\mathrm{Me}$ & 5.12 & -0.07 & $\begin{array}{l}\text { https://www.chemicalbook.com/ChemicalProductProperty_EN } \\
\text { CB1410011.htm }\end{array}$ \\
\hline 3 & 5 -Et & 4.12 & -0.07 & $\begin{array}{l}\text { https://www.chemicalbook.com/ChemicalProductProperty_EN } \\
\text { CB0160148.htm }\end{array}$ \\
\hline
\end{tabular}

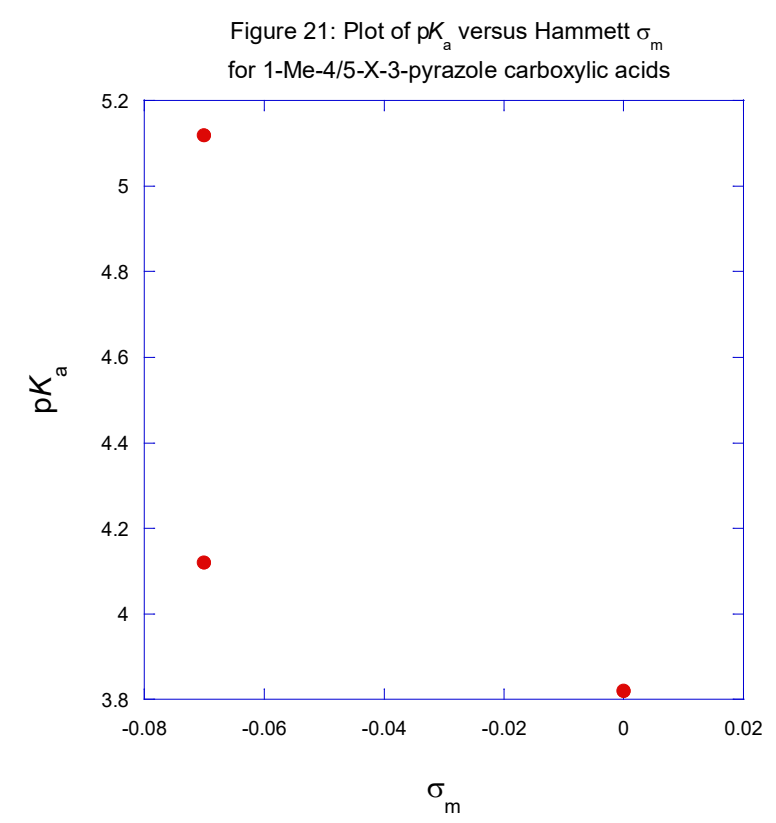

1-Me-3-X-4-pyrazole carboxylic acids:

Table 10: $\mathrm{p} K_{\mathrm{a}}$, Taft $\sigma_{\text {ortho }}^{*}$ values of 1-Me-3-X-4-pyrazole carboxylic acids

Table 10: $\mathrm{p} K_{\mathrm{a}}$, Taft $\sigma_{\text {ortho }}^{*}$ values of 1-Me-3-X-4-pyrazole carboxylic acids<smiles>[X]c1nn(C)cc1C(=O)O</smiles>

\begin{tabular}{|c|c|c|c|c|}
\hline Sl. No. & $X$ & $\mathrm{p} K_{\mathrm{a}}$ & $\begin{array}{c}\text { Taft } \\
\sigma_{\text {ortho }}^{*}\end{array}$ & Literature for $\mathrm{p} K_{\mathrm{a}}$ values \\
\hline 1 & $\mathrm{H}$ & 4.02 & 0.49 & \multirow{3}{*}{$\begin{array}{l}\text { Robert G. Franz, AAPS Pharmsci 2001; } 3 \text { (2) } \\
\text { article } 10 \text { (http://www.pharmsci.org/) }\end{array}$} \\
\hline 2 & $\mathrm{CF}_{3}$ & 3.79 & 2.61 & \\
\hline 3 & $\mathrm{CH}_{3}$ & 4.52 & 0.00 & \\
\hline
\end{tabular}




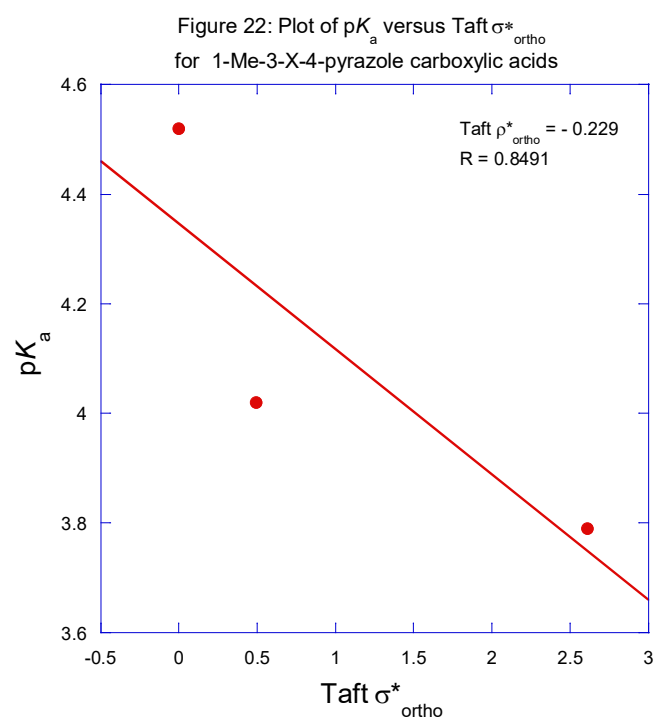

Solvolysis data for 5-X-2-furylmethylcarbinyl p-nitrobenzoates:

Table 11: Solvolysis data for 5-X-2-furylmethylcarbinyl p-nitrobenzoates in $80 \%$ aqueous ethanol at $25^{\circ} \mathrm{C}$

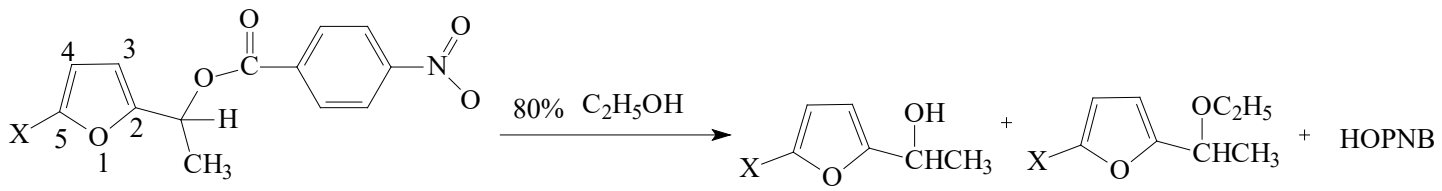

\begin{tabular}{|c|c|c|c|c|c|c|}
\hline \multirow{2}{*}{ S1. No. } & \multirow{2}{*}{$X$} & \multirow{2}{*}{$k_{\text {relative }}$} & \multicolumn{2}{|c|}{ Hammett } & \multirow{2}{*}{$\begin{array}{c}\text { Taft } \\
\sigma_{\text {ortho }}^{*}\end{array}$} & \multirow{2}{*}{ Literature for $k_{\text {relative }}$ values } \\
\hline & & & $\sigma_{p}$ & $\sigma_{\mathrm{m}}$ & & \\
\hline 1 & $\mathrm{Me}$ & 212 & -0.17 & -0.07 & 0.00 & \multirow{5}{*}{$\begin{array}{c}k_{\text {relative values are from Donald S. }} \text {. } \\
\text { Noyce and Gary V. Kaiser, J. } \\
\text { Org. Chem., vol. 34, page 1008, } \\
1969\end{array}$} \\
\hline 2 & $\mathrm{H}$ & 1.00 & 0.00 & 0.00 & 0.49 & \\
\hline 3 & $\mathrm{Br}$ & 0.271 & 0.23 & 0.39 & 2.84 & \\
\hline 4 & $\mathrm{COOC}_{2} \mathrm{H}_{5}$ & $3.70 \times 10^{-4}$ & 0.45 & 0.37 & 2.12 & \\
\hline 5 & $\mathrm{NO}_{2}$ & $1.45 \times 10^{-6}$ & 0.80 & 0.71 & 4.00 & \\
\hline
\end{tabular}

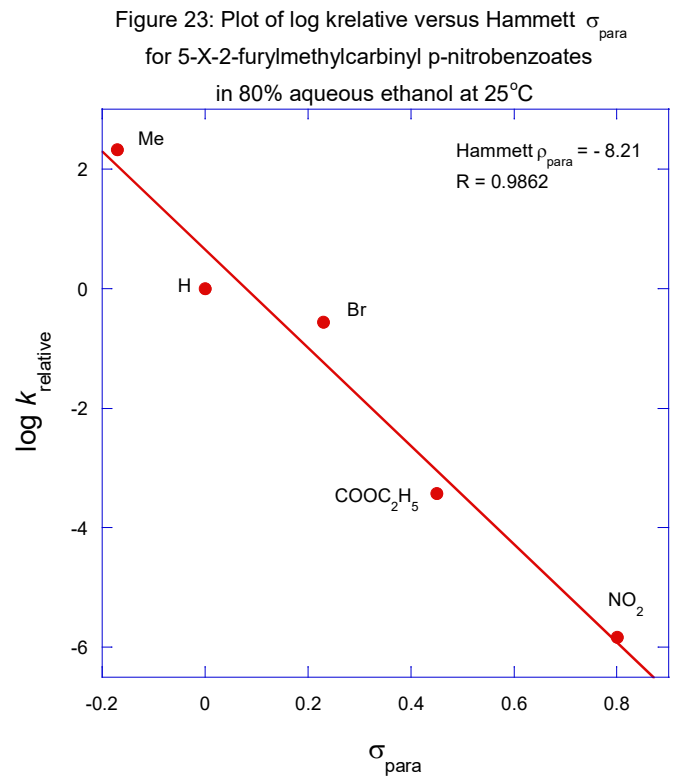




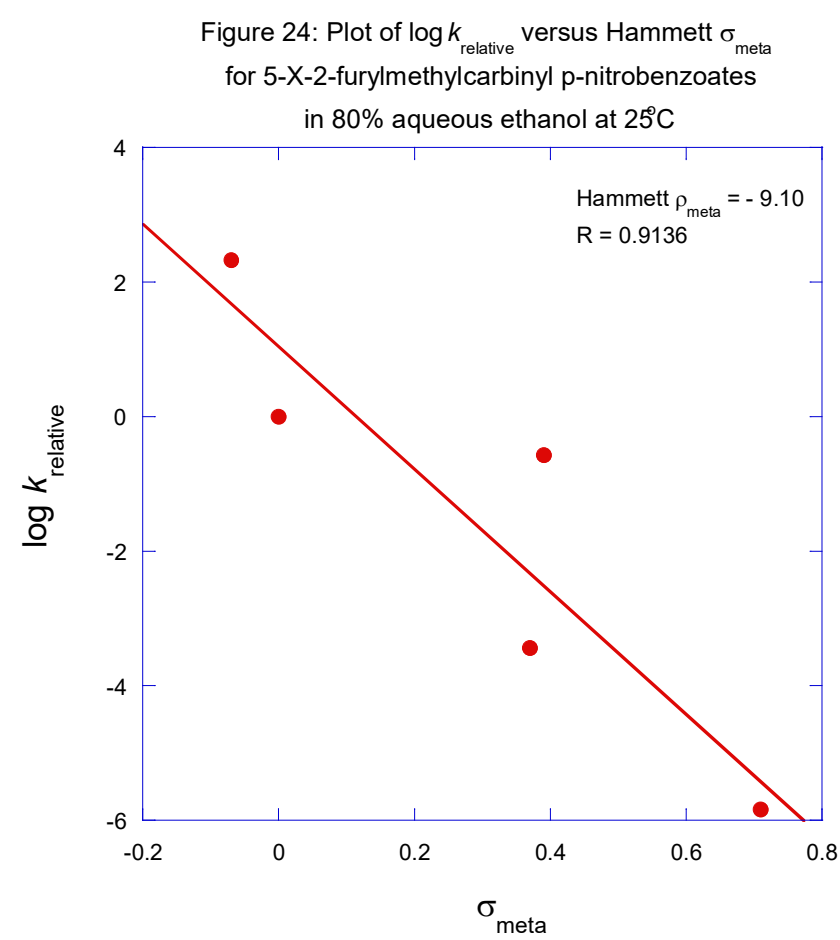

Figure 25: Plot of log $k_{\text {relative }}$ versus Taft $\sigma *{ }_{\text {ortho }}$ for 5-X-2-furylmethylcarbinyl p-nitrobenzoates in $80 \%$ aqueous ethanol at $25^{\circ} \mathrm{C}$

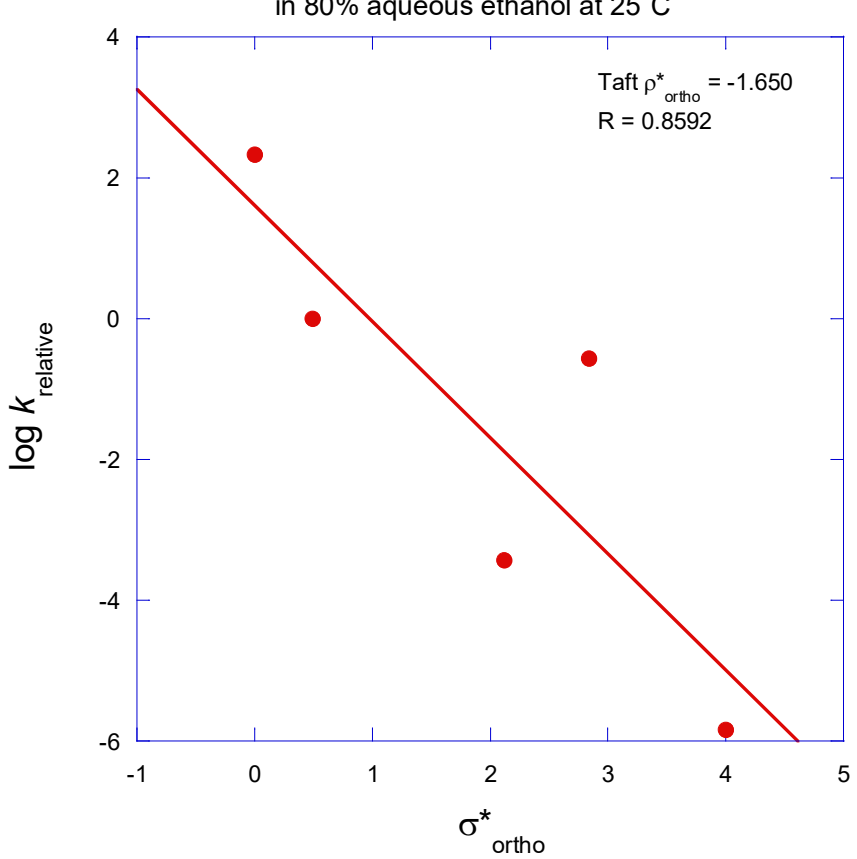


4-X-2-furylmethylcarbinyl p-nitrobenzoates:

Table 12: Solvolysis data for 4-X-2-furylmethylcarbinyl p-nitrobenzoates in $80 \%$ aqueous ethanol at $25^{\circ} \mathrm{C}$

\begin{tabular}{|c|c|c|c|c|c|}
\hline \multirow{2}{*}{ X } & \multirow{2}{*}{$k_{\text {relative }}$} & \multicolumn{2}{|c|}{ Hammett } & Taft & \multirow{2}{*}{ Literature for $k_{\text {relative }}$ values } \\
\hline & & $\sigma_{p}$ & $\sigma_{\mathrm{m}}$ & $\sigma_{\text {ortho }}^{*}$ & \\
\hline $\mathrm{H}$ & 1.00 & 0.00 & 0.00 & 0.49 & \multirow{3}{*}{$\begin{array}{l}k_{\text {relative values are from Donald S }} \\
\text { Noyce and Gary V. Kaiser, J. Org } \\
\text { Chem., vol. 34, page 1008, } 1969\end{array}$} \\
\hline $\mathrm{Br}$ & $4.76 \times 10^{-3}$ & 0.23 & 0.39 & 2.84 & \\
\hline $\mathrm{COOC}_{2} \mathrm{H}_{5}$ & $7.67 \times 10^{-4}$ & 0.45 & 0.37 & 2.12 & \\
\hline
\end{tabular}
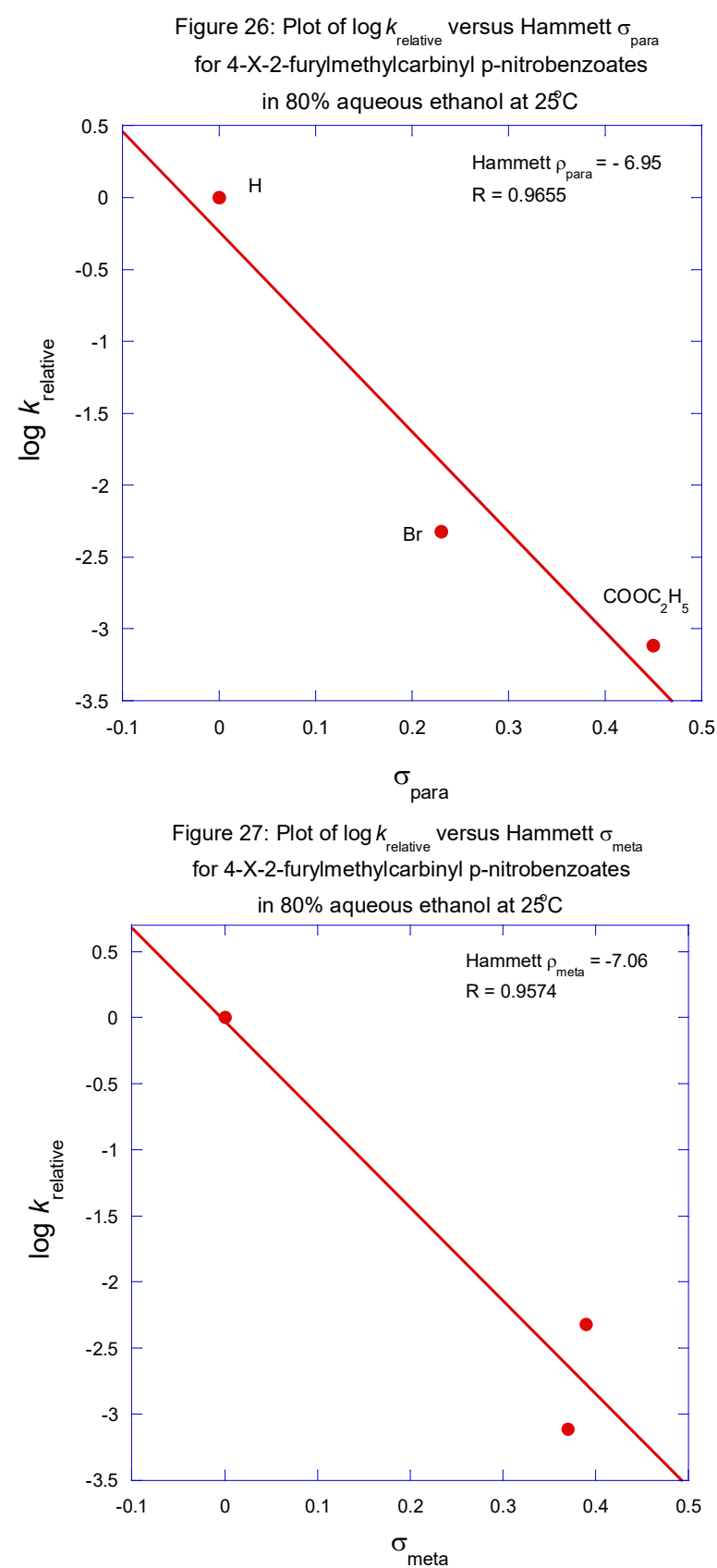

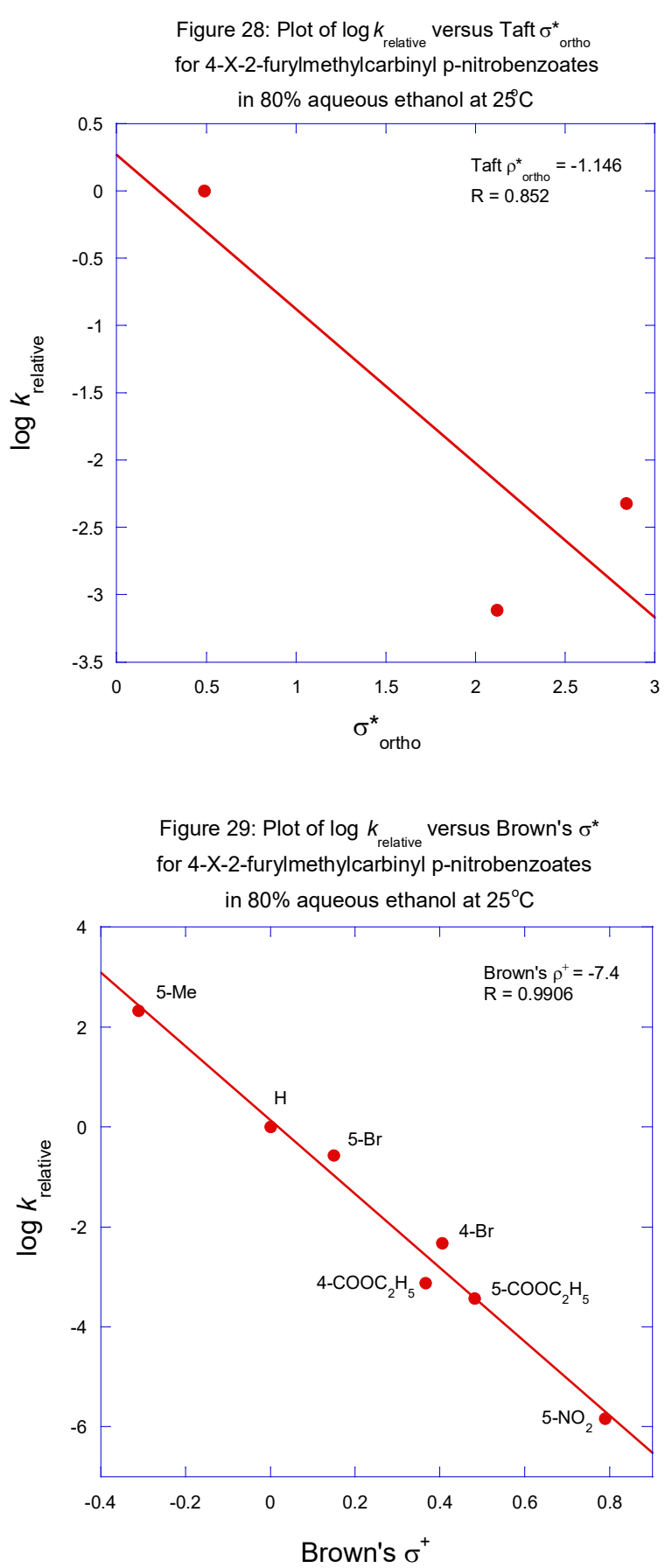

Brown's $\sigma^{+}$values are from Y. Okamoto and H. C. Brown J. Am. Chem. Soc., 80, 4979 (1958)

The rate constants $k_{\text {relative }}$ of the solvolysis of 5-X-2-furylmethylcarbinyl p-nitro benzoates and 4-X-2-furylmethylcarbinyl p-nitro benzoates were originally treated with Brown's $\sigma^{+}$ values [20]. As the $\sigma^{+}$values are free from the mesomeric effects, the correlation was good irrespective of the position of the substituent [20]. In the insight of the present work, we have tried the correlation of the rate data of the solvolysis of 5-X-2-furylmethylcarbinyl p-nitro benzoates and 4-X-2-furylmethylcarbinyl p-nitro benzoates separately assuming 5-X substituted derivatives as para-substituents and $4-\mathrm{X}$ substituted derivatives as meta- 
substituents because it was shown that the 5 and 4 positions of 5 -membered heterocycles just correspond to the para and meta positions of benzene ring [13, 14]. Consequently, the rates of solvolysis of 5-X-2-furylmethylcarbinyl p-nitro benzoates correlated well with $\sigma_{\text {para }}$ (figure 23) with a correlation coefficient of 0.9862 and the rates of solvolysis of 4-X-2furylmethylcarbinyl p-nitro benzoates correlated well with $\sigma_{\text {meta }}$ (figure 27 ) with a correlation coefficient of 0.9574 .

$\mathrm{MnO}_{4}^{-}$oxidation of 5-X-furfurals:

Table 13: Rate data of $\mathrm{MnO}_{4}^{-}$oxidation of 5-X-furfurals in aqueous neutral medium

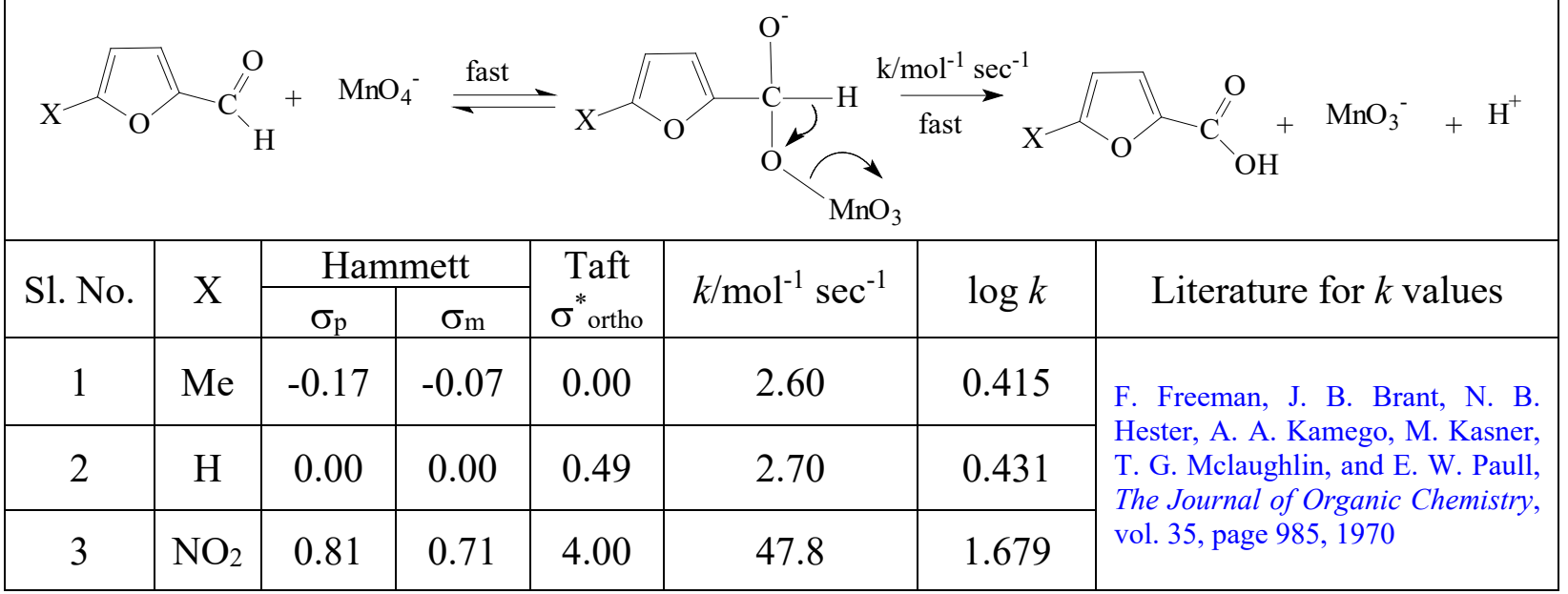

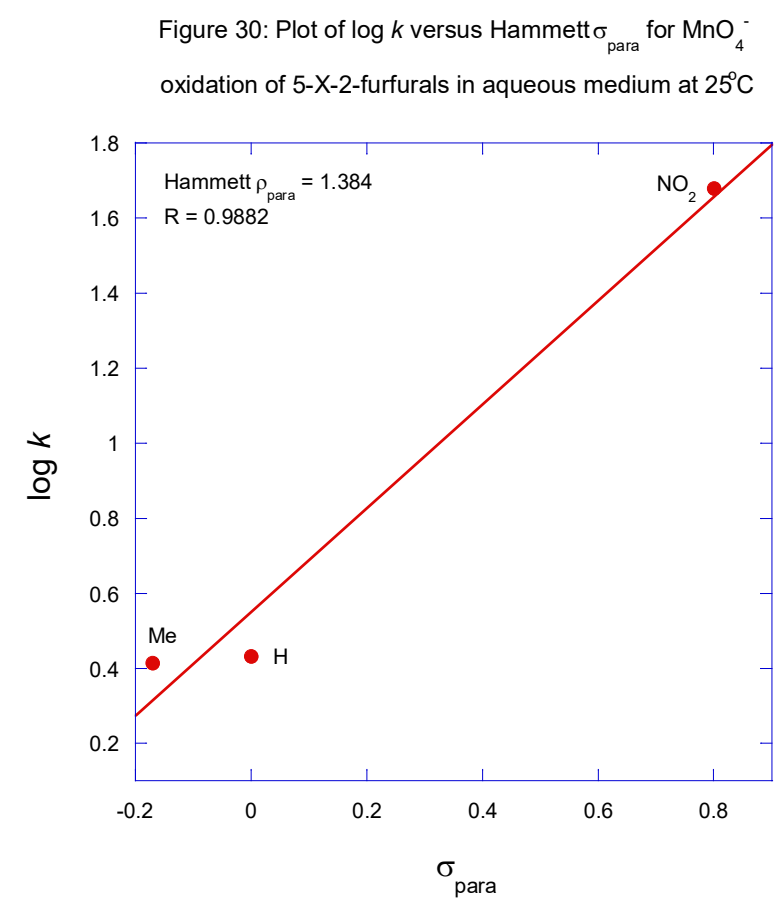



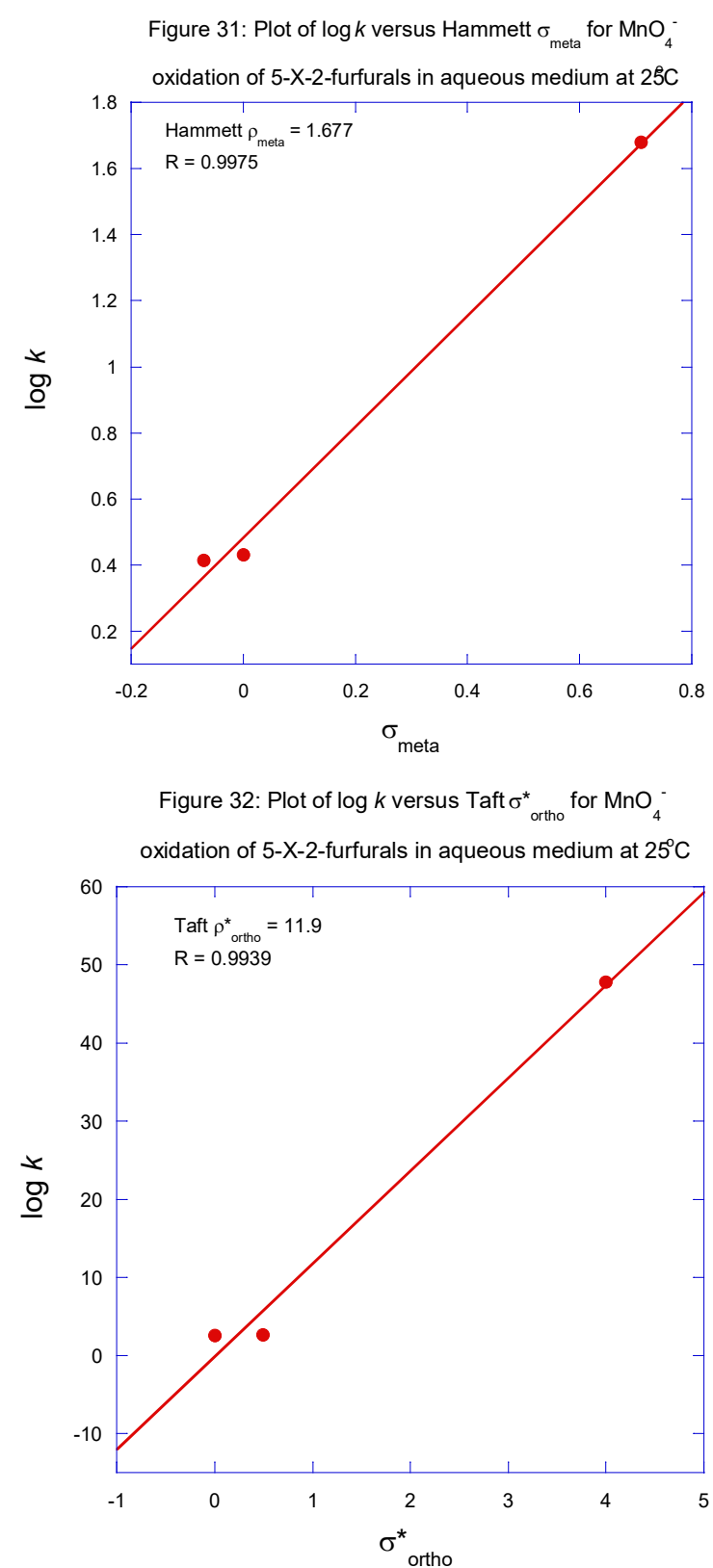

Rate data of $\mathrm{MnO}_{4}^{-}$oxidation of 5-X-furfurals in aqueous neutral medium [21] correlated well with all the Hammett and Taft substituent constants for which we could not give any explanation. Yet the correlation with Hammett $\sigma$ meta is slightly better $(\mathrm{R}=0.9975)$ than the other two. This could be possible as the substituent and the functional group are separated by a pair of non-bonded electrons which come from oxygen (see scheme 3 structure $\mathbf{E}$ and $\mathbf{F}$ ). However, Freeman reported [21] the Hammett plot $\log k_{2}$ versus $\sigma$ for $\mathrm{MnO}_{4}^{-}$oxidation of 5$\mathrm{X}$-furfurals in aqueous neutral and basic medium with substituents $\mathrm{X}=\mathrm{H}, \mathrm{Me}, \mathrm{n}-\mathrm{Bu}, \mathrm{Et}, \mathrm{Cl}$ and $\mathrm{Br}$. Though $\mathrm{MnO}_{4}^{-}$oxidation of 5-X-furfurals with $\mathrm{X}=\mathrm{NO}_{2}$ studied, but not shown in the Hammett plot. But the data is not available in this publication except the Hammett plot. Therefore, it was not possible to analyze the data in detail in the present study. 
Table 14: $\mathrm{p} K_{\mathrm{a}}$, Hammett $\sigma_{\mathrm{p}}, \sigma_{\mathrm{m}}$ and Taft $\sigma_{\text {ortho }}^{*}$ values of 5-X-1, 2, 3-triazole-4-carboxylic acids

\begin{tabular}{|c|c|c|c|c|c|c|}
\hline & & & & ${ }_{2}^{\mathrm{N}} \sum_{3}^{\mathrm{N}} \sum_{\mathrm{H}}^{\mathrm{X}}$ & $\mathrm{H}$ & \\
\hline Sl. No. & $\mathrm{X}$ & $\mathrm{p} K_{\mathrm{a}}$ & $\begin{array}{l}\text { Taft } \\
\sigma_{\text {ortho }}^{*}\end{array}$ & $\begin{array}{c}\mathrm{F}^{\mathrm{a}} \\
\text { (field effect } \\
\text { contribution) }\end{array}$ & $\begin{array}{c}\mathrm{R}^{\mathrm{a}} \\
\text { (resonance } \\
\text { effect } \\
\text { contribution) }\end{array}$ & Literature for $\mathrm{p} K_{\mathrm{a}}$ values \\
\hline 1 & $\mathrm{H}$ & 3.22 & 0.49 & 0.00 & 0.00 & $\begin{array}{l}\text { https://www.chemicalbook.com/Chemica } \\
\text { lProductProperty EN CB1683581.htm }\end{array}$ \\
\hline 2 & $\mathrm{COOH}$ & 1.86 & 2.08 & 0.44 & 0.66 & $\begin{array}{l}\text { https://www.chemicalbook.com/Chemica } \\
\text { IProductProperty_EN CB6756385.htm }\end{array}$ \\
\hline 3 & $\mathrm{CF}_{3}$ & 2.76 & 2.61 & 0.64 & 0.76 & $\begin{array}{l}\text { https://m.chemicalbook.com/ChemicalPr } \\
\text { oductPropertyEN CB83172313.htm }\end{array}$ \\
\hline
\end{tabular}

${ }^{\mathrm{a}} \mathrm{F}$ and $\mathrm{R}$ values are from J. March, Advanced organic Chemistry, $4^{\text {th }}$ Edition, Wiley-Interscience, New York, 1992, page 284 .

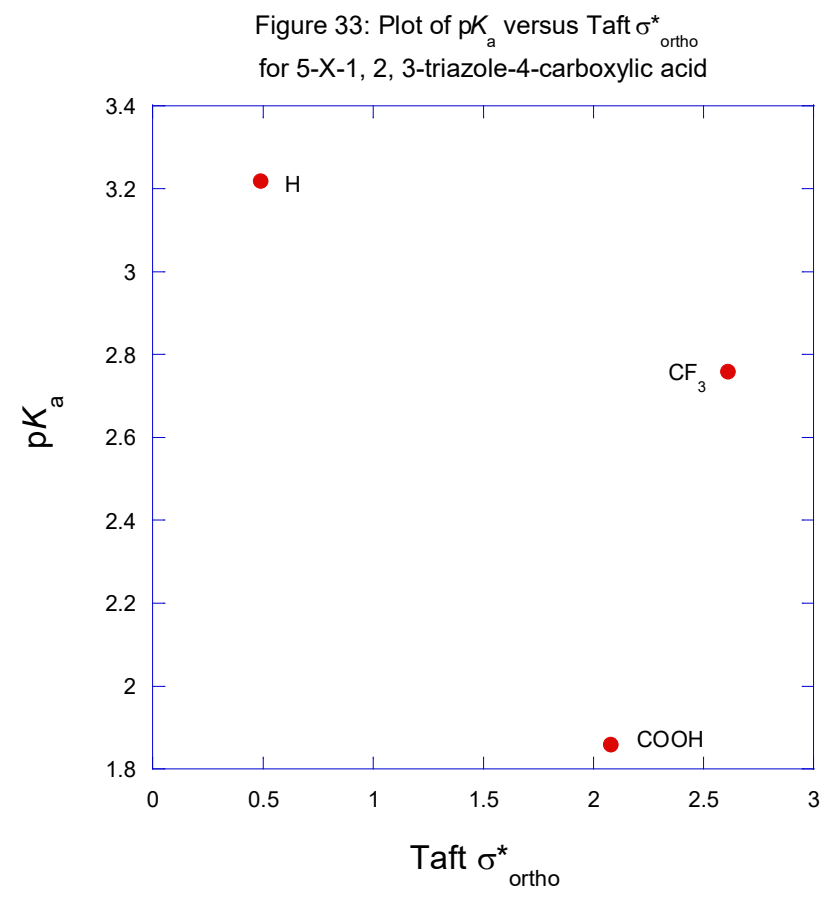


Figure 34: Plot of $p K_{a}$ versus $F($ field effect contribution)

for 5-X-1, 2, 3-triazole-4-carboxylic acid

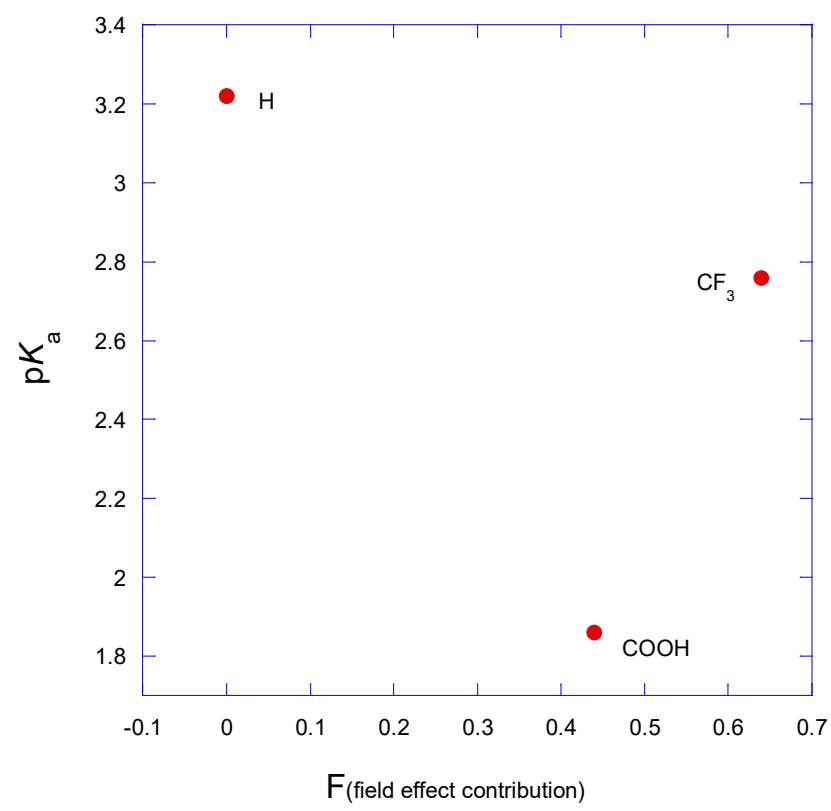

Figure 35: Plot of $\mathrm{pK}_{\mathrm{a}}$ versus $\mathrm{R}$ (resonance effect contribution) for 5-X-1, 2, 3-triazole-4-carboxylic acid

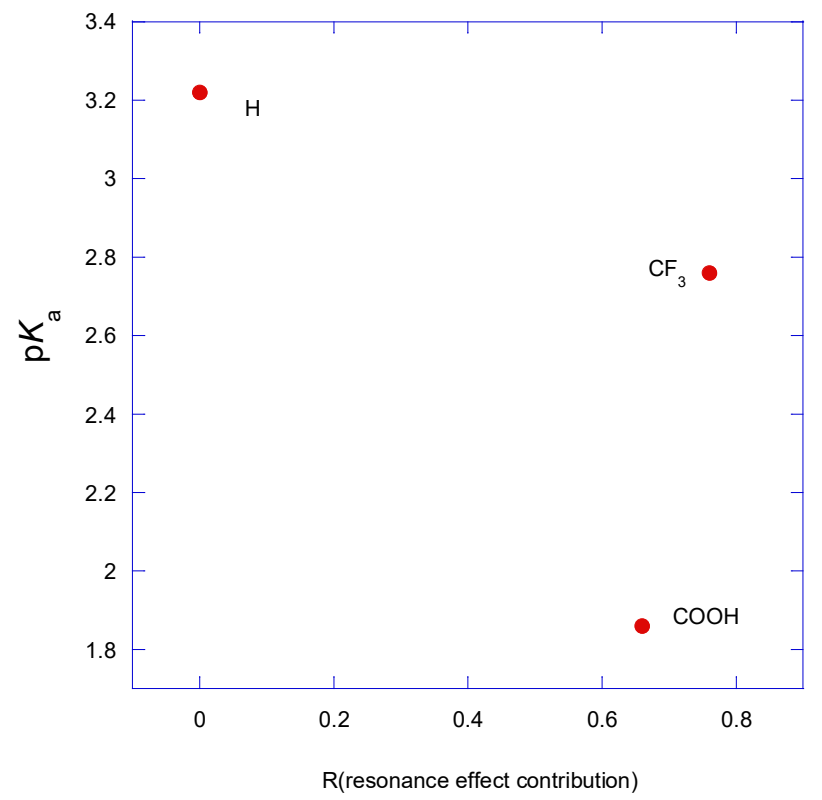

The plot of $\mathrm{p} K_{\mathrm{a}}$ versus Taft $\sigma^{*}{ }_{\text {ortho }}$ (figure 33) is not linear. Then we thought that using Swain and Lupton type equation $(\sigma=f \mathrm{~F}+r \mathrm{R})$ [22] and plotting $\mathrm{p} K$ a versus $\mathrm{F}$ (field effect contribution) (figure 34 ) and $\mathrm{p} K_{\mathrm{a}}$ versus $\mathrm{R}$ (resonance effect contribution) (figure 35 ) to see the individual field and resonance effects on the acid dissociation. But none of them are linear. The non-linearity of any of the three plots could possibly be due to the involvement of 
various types of intramolecular hydrogen bondings in 5-X-1, 2, 3-triazole-4-carboxylic acids as shown below in scheme 11 .<smiles></smiles><smiles>OC1=CC=N[IH]N1</smiles><smiles>O=C1O[In]n2nnc(I)c21</smiles><smiles></smiles><smiles></smiles>

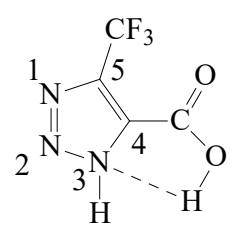

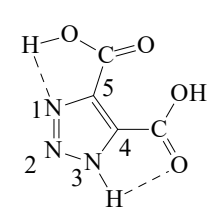<smiles></smiles><smiles>O=C1OCOC(O)c2nnnn21</smiles><smiles>O=C1O[CH]OC(=O)n2nnnc21</smiles>

Scheme 11

Due to the presence of these hydrogen bonding any of the substituent does not behave as if it is a pure isolated substituent, hence the non-linearity in the $\mathrm{p} K_{\mathrm{a}}$ versus Taft $\sigma^{*}$ ortho, $\mathrm{p} K_{\mathrm{a}}$ versus $\mathrm{F}$ and $\mathrm{p} K_{\mathrm{a}}$ versus $\mathrm{R}$ plots.

3-X-Pyrroles:

Table 15: $\mathrm{p} K_{\mathrm{a}}$, Hammett $\sigma_{\mathrm{p}}, \sigma_{\mathrm{m}}$ and Taft $\sigma_{\text {ortho }}^{*}$ values of 3-X-Pyrroles

\begin{tabular}{|c|c|c|c|c|c|c|}
\hline & & & & & $5^{4}$ & $X$ \\
\hline \multirow{2}{*}{ Sl. No. } & \multirow{2}{*}{$X$} & \multirow{2}{*}{$\mathrm{p} K_{\mathrm{a}}$} & \multicolumn{2}{|c|}{ Hammett } & \multirow{2}{*}{$\begin{array}{c}\text { Taft } \\
\sigma_{\text {ortho }}^{*}\end{array}$} & \multirow{2}{*}{ Literature for $\mathrm{p} K_{\mathrm{a}}$ values } \\
\hline & & & $\sigma_{\mathrm{p}}$ & $\sigma_{\mathrm{m}}$ & & \\
\hline 1 & $\mathrm{H}$ & 16.5 & 0.00 & 0.00 & 0.49 & $\begin{array}{l}\text { https://en.wikipedia.org/wiki/Pyrrole } \\
\text { Gerhartz, W. (exec ed.). Ullmann's Encyclopedia of Industrial } \\
\text { Chemistry. 5th ed.Vol A1: Deerfield Beach, FL: VCH Publishers, } \\
1985 \text { to Present., p. A22 (93) } 453 \\
\text { Perrin DD; Dissociation constants of organic bases in aqueous solution } \\
\text { IUPAC Chem Data Ser, Buttersworth, London (1965) }\end{array}$ \\
\hline 2 & $\mathrm{Me}$ & 17.3 & -0.17 & -0.07 & 0.00 & $\begin{array}{l}\text { https://www.chemicalbook.com/ChemicalProductProperty_EN_CB51 } \\
46220 \text {.htm }\end{array}$ \\
\hline 3 & $\mathrm{Br}$ & 15.33 & 0.23 & 0.39 & 2.84 & $\begin{array}{l}\text { https://m.chemicalbook.com/ProductChemicalPropertiesCB6339708 } \\
\text { EN.htm }\end{array}$ \\
\hline 4 & $\mathrm{NO}_{2}$ & 13.96 & 0.80 & 0.71 & 4.00 & $\begin{array}{l}\text { https://www.chemicalbook.com/ChemicalProductProperty_EN_CB32 } \\
09956 . \text { htm }\end{array}$ \\
\hline
\end{tabular}




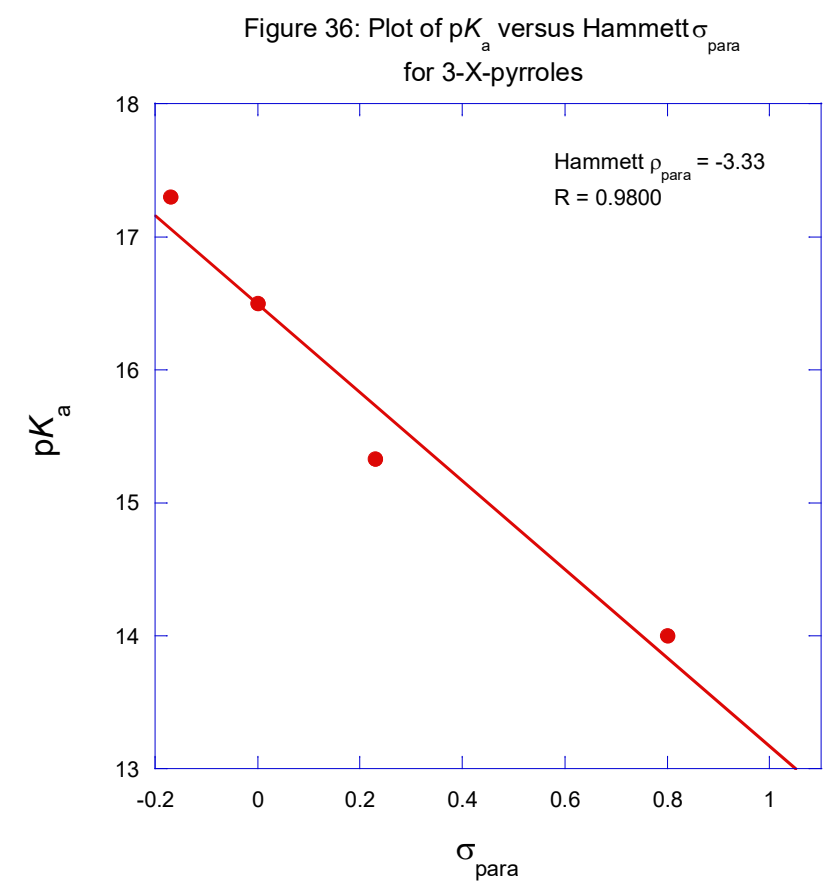

Figure 37: Plot of $\mathrm{pK}_{\mathrm{a}}$ versus Hammett $\sigma_{\text {meta }}$ for 3-X-pyrroles

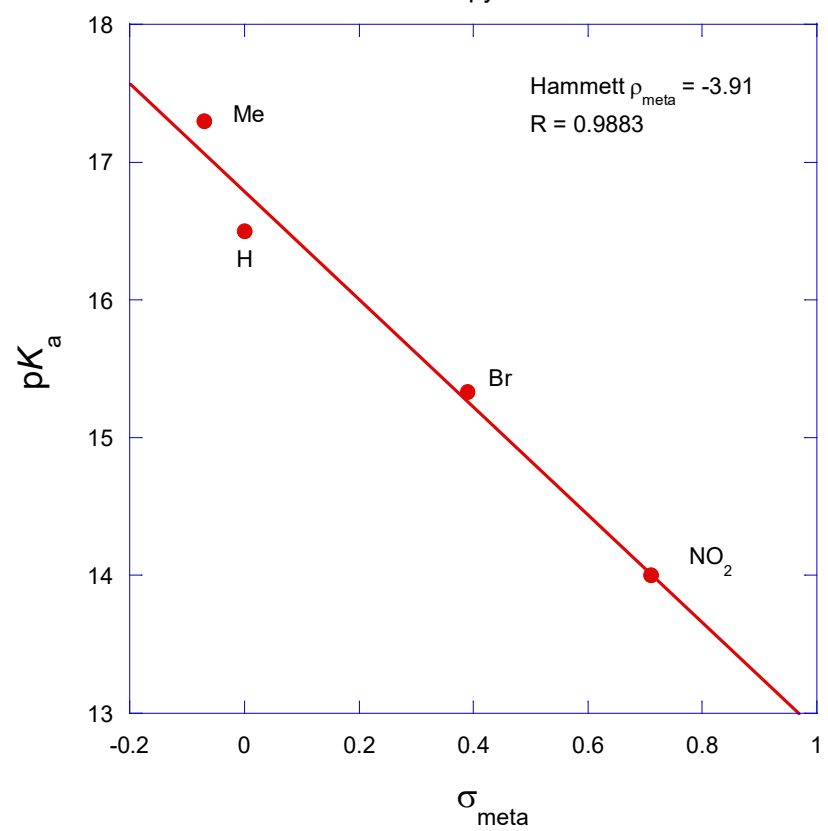




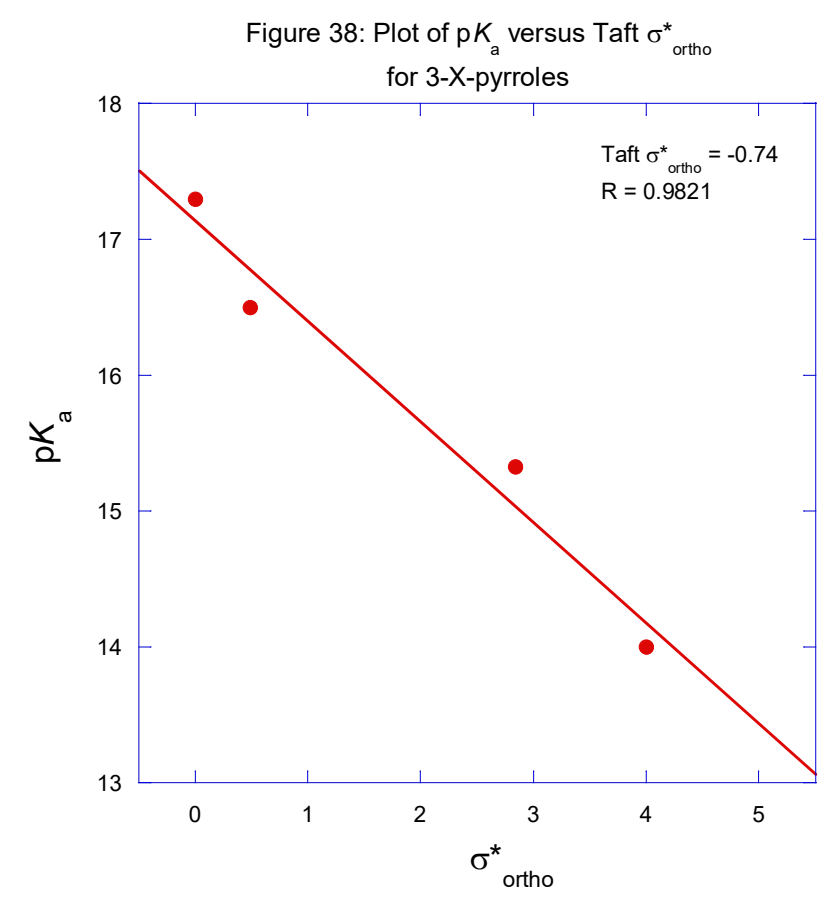

In the figures 36-38 it is clear from the correlation coefficients, the $\mathrm{p} K_{\mathrm{a}}$ data of 3-X-pyrroles correlated well (Hammett $\rho_{\mathrm{m}}=-3.91, \mathrm{R}=0.9883$ ) with Hammett $\sigma_{\mathrm{m}}$ values. Therefore the 3 position of the 3-X-pyrroles is best assumed as meta-position.

3-X-pyrazoles:

\begin{tabular}{|c|c|c|c|c|c|c|}
\hline \multicolumn{7}{|c|}{ Table 16: $\mathrm{p} K_{\mathrm{a}}$, Hammett $\sigma_{\mathrm{p}}, \sigma_{\mathrm{m}}$ and Taft $\sigma_{\text {ortho }}^{*}$ values of 3-X-pyrazoles } \\
\hline & & & & & H & \\
\hline \multirow{2}{*}{ Sl. No. } & \multirow{2}{*}{$X$} & \multirow{2}{*}{$\mathrm{p} K_{\mathrm{a}}$} & \multicolumn{2}{|c|}{ Hammett } & Taft & \multirow{2}{*}{ Literature for $\mathrm{p} K_{\mathrm{a}}$ values } \\
\hline & & & $\sigma_{\mathrm{p}}$ & $\sigma_{\mathrm{m}}$ & $\sigma_{\text {ortho }}^{*}$ & \\
\hline 1 & $\mathrm{H}$ & 14.2 & 0.00 & 0.00 & 0.49 & $\begin{array}{l}\text { https://www.imperial.ac.uk/media/imperial- } \\
\text { college/research-centres-and-groups/spivey- } \\
\text { group/teaching/org2heteroaromatics/lecture81112.pdf }\end{array}$ \\
\hline 2 & $\mathrm{Cl}$ & 11.04 & 0.23 & 0.37 & 2.96 & $\begin{array}{l}\text { https://www.chemicalbook.com/ChemicalProductPrope } \\
\mathrm{rty} \text { EN CB42593960.htm }\end{array}$ \\
\hline 3 & $\mathrm{Me}$ & 14.56 & -0.17 & -0.07 & 0.00 & $\begin{array}{l}\text { https://www.chemicalbook.com/ChemicalProductPrope } \\
\text { rty_EN_CB3198957.htm }\end{array}$ \\
\hline 4 & $\mathrm{Br}$ & 10.88 & 0.23 & 0.39 & 2.84 & $\begin{array}{l}\text { https://www.chemicalbook.com/ChemicalProductPrope } \\
\text { rty EN CB1121665.htm }\end{array}$ \\
\hline 5 & $\mathrm{CN}$ & 10.3 & 0.66 & 0.56 & 3.30 & $\begin{array}{l}\text { https://www.chemicalbook.com/ChemicalProductPrope } \\
\text { rty EN_CB6384364.htm }\end{array}$ \\
\hline 6 & $\mathrm{NO}_{2}$ & 8.32 & 0.80 & 0.71 & 4.00 & $\begin{array}{l}\text { https://www.chemicalbook.com/ChemicalProductPrope } \\
\text { rty EN CB7744572.htm }\end{array}$ \\
\hline 7 & $\mathrm{NH}_{2}$ & 15.28 & -0.66 & -0.16 & 0.62 & $\begin{array}{l}\text { https://www.chemicalbook.com/ChemicalProductPrope } \\
\text { rty EN CB2322586.htm }\end{array}$ \\
\hline 8 & $\mathrm{CF}_{3}$ & 10.56 & 0.54 & 0.43 & 2.61 & $\begin{array}{l}\text { https://www.chemicalbook.com/ChemicalProductPrope } \\
\text { rty EN CB3681435.htm }\end{array}$ \\
\hline
\end{tabular}



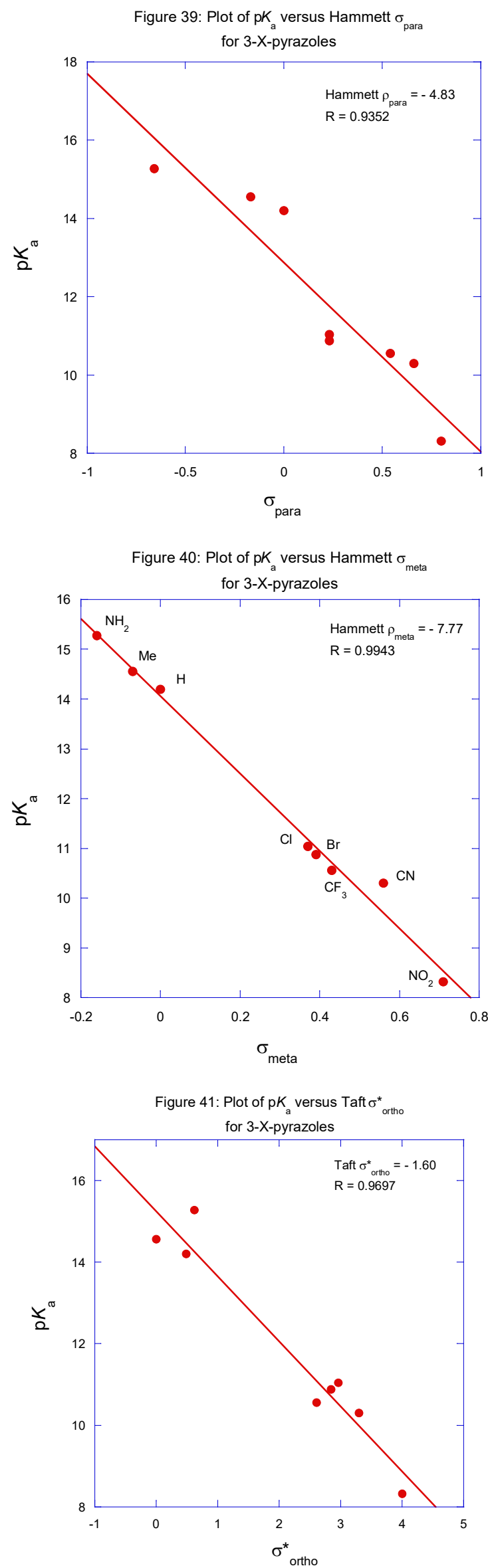
In the figures 39-41 it is clear from the correlation coefficients, the $\mathrm{p} K_{\mathrm{a}}$ data of $3-\mathrm{X}$-pyrazoles correlated well (Hammett $\rho_{\text {meta }}=-7.77, \mathrm{R}=0.9943$ ) with Hammett $\sigma_{\mathrm{m}}$ values. Therefore the 3 position of the 3-X-pyrazoles is best assumed as meta-position.

\section{4-X-pyrazoles:}

\begin{tabular}{|c|c|c|c|c|c|c|}
\hline \multicolumn{7}{|c|}{ Table 17: $\mathrm{p} K_{\mathrm{a}}$, Hammett $\sigma_{\mathrm{p}}, \sigma_{\mathrm{m}}$ and Taft $\sigma_{\text {ortho }}^{*}$ values of 4-X-pyrazoles } \\
\hline \multicolumn{7}{|c|}{$\mathrm{X}$} \\
\hline \multirow{2}{*}{ Sl. No. } & \multirow{2}{*}{$X$} & \multirow{2}{*}{$\mathrm{p} K_{\mathrm{a}}$} & \multicolumn{2}{|c|}{ Hammett } & Taft & \multirow{2}{*}{ Literature for $\mathrm{p} K_{\mathrm{a}}$ values } \\
\hline & & & $\sigma_{\mathrm{p}}$ & $\sigma_{\mathrm{m}}$ & $\sigma_{\text {ortho }}^{*}$ & \\
\hline 1 & $\mathrm{H}$ & 14.2 & 0.00 & 0.00 & 0.49 & $\begin{array}{l}\text { https://www.imperial.ac.uk/media/imperial- } \\
\text { college/research-centres-and-groups/spivey- } \\
\text { group/teaching/org2heteroaromatics/lecture81112.pdf }\end{array}$ \\
\hline 2 & $\mathrm{Cl}$ & 12.71 & 0.23 & 0.37 & 2.96 & $\begin{array}{l}\text { https://www.chemicalbook.com/ChemicalProductPrope } \\
\text { rty EN CB2212438.htm }\end{array}$ \\
\hline 3 & $\mathrm{Me}$ & 14.95 & -0.17 & -0.07 & 0.00 & $\begin{array}{l}\text { https://www.chemicalbook.com/ChemicalProductPrope } \\
\text { rty_EN_CB8233079.htm }\end{array}$ \\
\hline 4 & $\mathrm{Br}$ & 12.7 & 0.23 & 0.39 & 2.84 & $\begin{array}{l}\text { https://www.chemicalbook.com/ChemicalProductPrope } \\
\text { rty EN CB6158239.htm }\end{array}$ \\
\hline 5 & $\mathrm{CN}$ & 10.3 & 0.66 & 0.56 & 3.30 & $\begin{array}{l}\text { https://www.chemicalbook.com/ChemicalProductPrope } \\
\text { rty EN CB6384364.htm }\end{array}$ \\
\hline 6 & $\mathrm{NO}_{2}$ & 9.63 & 0.80 & 0.71 & 4.00 & $\begin{array}{l}\text { https://www.chemicalbook.com/ChemicalProductPrope } \\
\text { rty EN CB6418845.htm }\end{array}$ \\
\hline
\end{tabular}

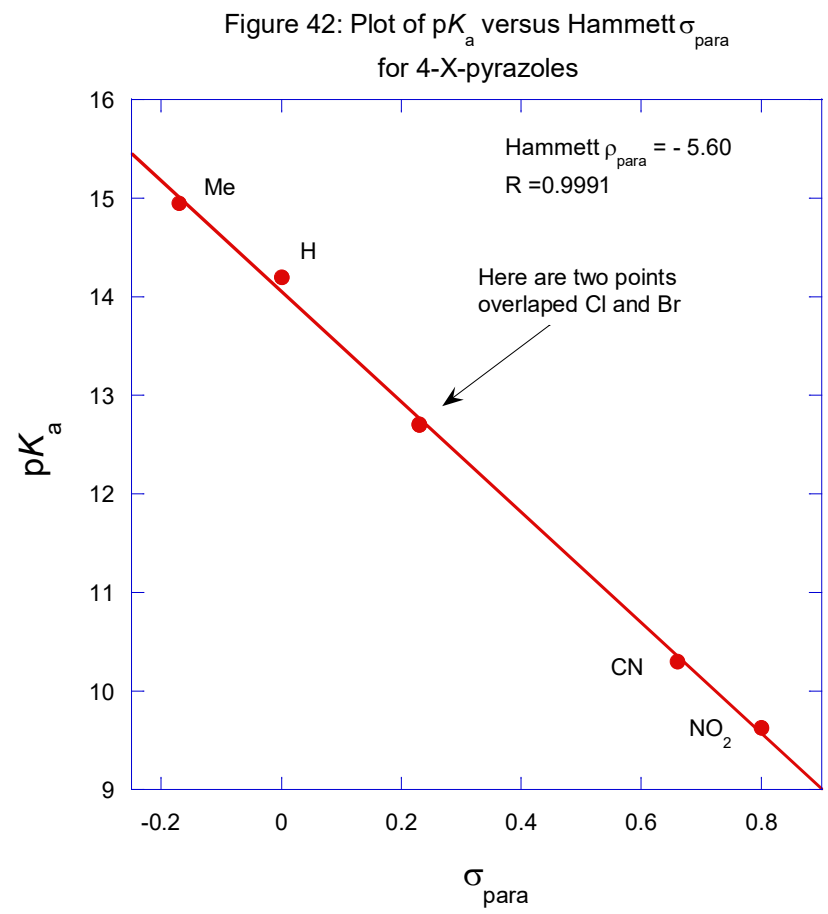



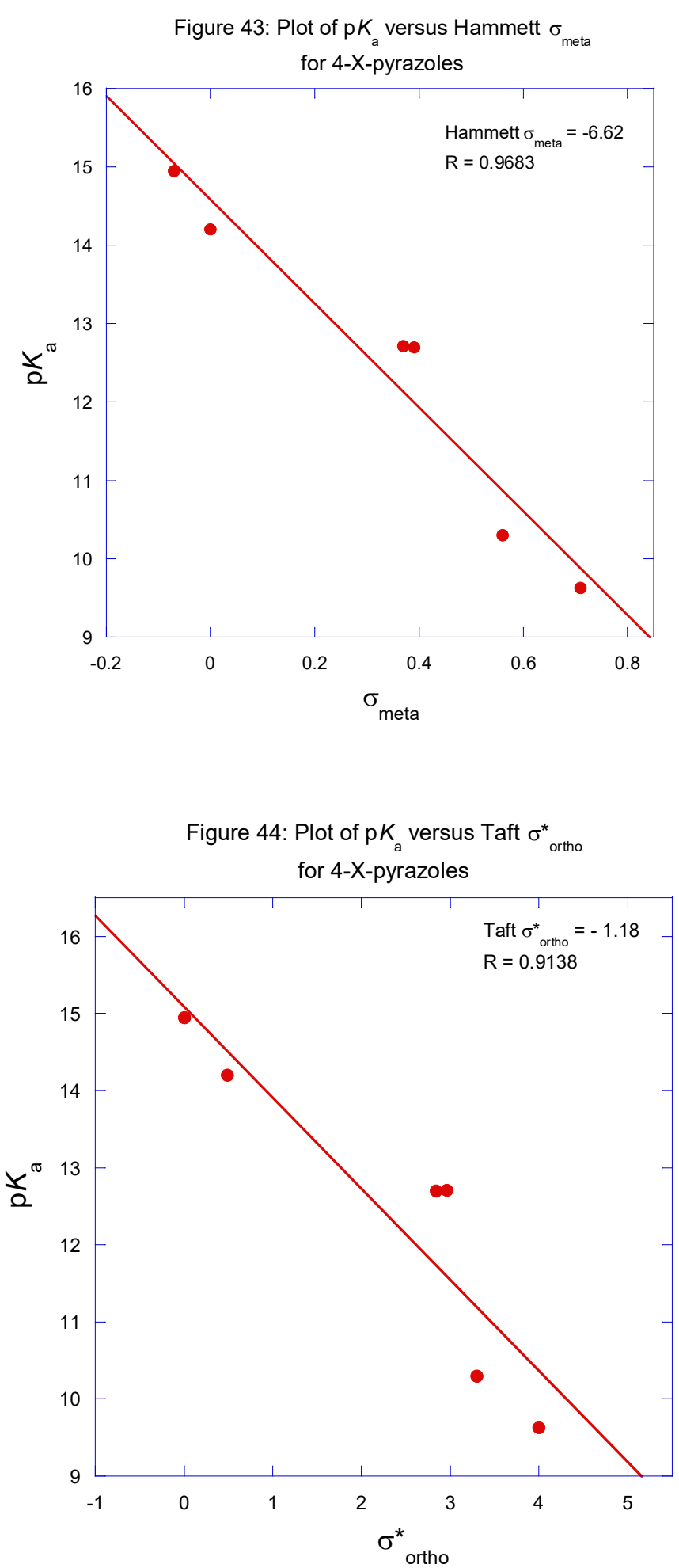

In the case of 4-X-pyrazoles the Hammett equation would have satisfied with $\sigma_{\text {meta }}$ values as the functional group $(\mathrm{N} 1 \mathrm{H})$ is only separated by a sp2 carbon as shown in the scheme $12 \mathbf{A}$. But in the figures 42-44 it is clear from the correlation coefficients, the $\mathrm{p} K_{\mathrm{a}}$ data of $4-\mathrm{X}$ pyrazoles correlated well (Hammett $\left.\rho_{\text {para }}=-5.60, \mathrm{R}=0.9991\right)$ with Hammett $\sigma_{\text {para }}$ values. Therefore the 4 position of the 4-X-pyrazoles is best assumed as para-position. And the 
substituent effect may best be transmitted via $\mathrm{sp} 2$ carbon and $\mathrm{sp} 2$ nitrogen as shown in scheme 12 B.

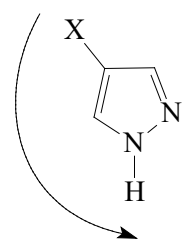

A

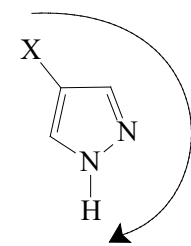

B

Scheme 12

\section{4-X-imidazoles:}

Table 18: $\mathrm{p} K_{\mathrm{a}}$, Hammett $\sigma_{\mathrm{p}}, \sigma_{\mathrm{m}}$ and Taft $\sigma_{\text {ortho }}^{*}$ values of 4-X-imidazoles

\begin{tabular}{|c|c|c|c|c|c|c|}
\hline & & & & X & $\begin{array}{c}-\mathrm{N} \\
\mathrm{N}^{-} \\
1 \\
\mathrm{H}\end{array}$ & \\
\hline \multirow{2}{*}{ S1. No. } & \multirow{2}{*}{$\mathrm{X}$} & \multirow{2}{*}{$\mathrm{p} K_{\mathrm{a}}$} & \multicolumn{2}{|c|}{ Hammett } & \multirow{2}{*}{$\begin{array}{c}\text { Taft } \\
\sigma_{\text {ortho }}^{*}\end{array}$} & \multirow{2}{*}{ Literature for $\mathrm{p} K_{\mathrm{a}}$ values } \\
\hline & & & $\sigma_{p}$ & $\sigma_{\mathrm{m}}$ & & \\
\hline 1 & $\mathrm{H}$ & 14.5 & 0.00 & 0.00 & 0.49 & $\begin{array}{l}\text { https://www.imperial.ac.uk/media/imperial- } \\
\text { college/research-centres-and-groups/spivey- } \\
\text { group/teaching/org2heteroaromatics/lecture81112.pdf }\end{array}$ \\
\hline 2 & $\mathrm{Cl}$ & 11.7 & 0.23 & 0.37 & 2.96 & $\begin{array}{l}\text { https://www.chemicalbook.com/ChemicalProductPrope } \\
\text { rty EN CB2825830.htm }\end{array}$ \\
\hline 3 & $\mathrm{Me}$ & 14.78 & -0.17 & -0.07 & 0.00 & https://www.drugbank.ca/drugs/DB03385 \\
\hline 4 & $\mathrm{Br}$ & 11.7 & 0.23 & 0.39 & 2.84 & $\begin{array}{l}\text { https://www.chemicalbook.com/ChemicalProductPrope } \\
\text { rty EN CB4300919.htm }\end{array}$ \\
\hline 5 & $\mathrm{NO}_{2}$ & 8.31 & 0.80 & 0.71 & 4.00 & $\begin{array}{l}\text { https://www.chemicalbook.com/ChemicalProductPrope } \\
\text { rty_EN_CB } 8774477 . \mathrm{htm}\end{array}$ \\
\hline 6 & $\mathrm{CN}$ & 10.3 & 0.66 & 0.56 & 3.30 & $\begin{array}{l}\text { https://www.chemicalbook.com/ChemicalProductPrope } \\
\text { rty EN CB8763109.htm }\end{array}$ \\
\hline 7 & $\mathrm{C}_{6} \mathrm{H}_{5}$ & 13.58 & -0.01 & 0.06 & 0.60 & $\begin{array}{l}\text { https://www.chemicalbook.com/ChemicalProductPrope } \\
\text { rty EN CB6252973.htm }\end{array}$ \\
\hline
\end{tabular}

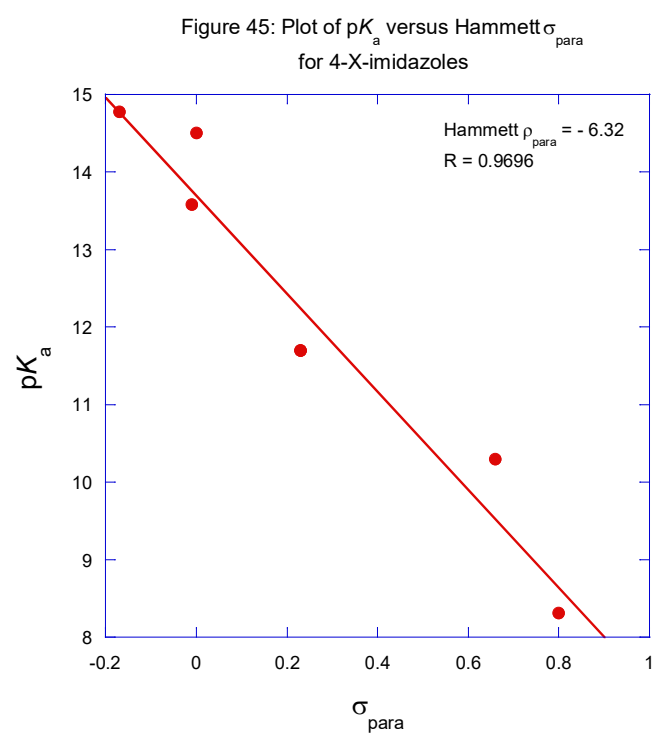



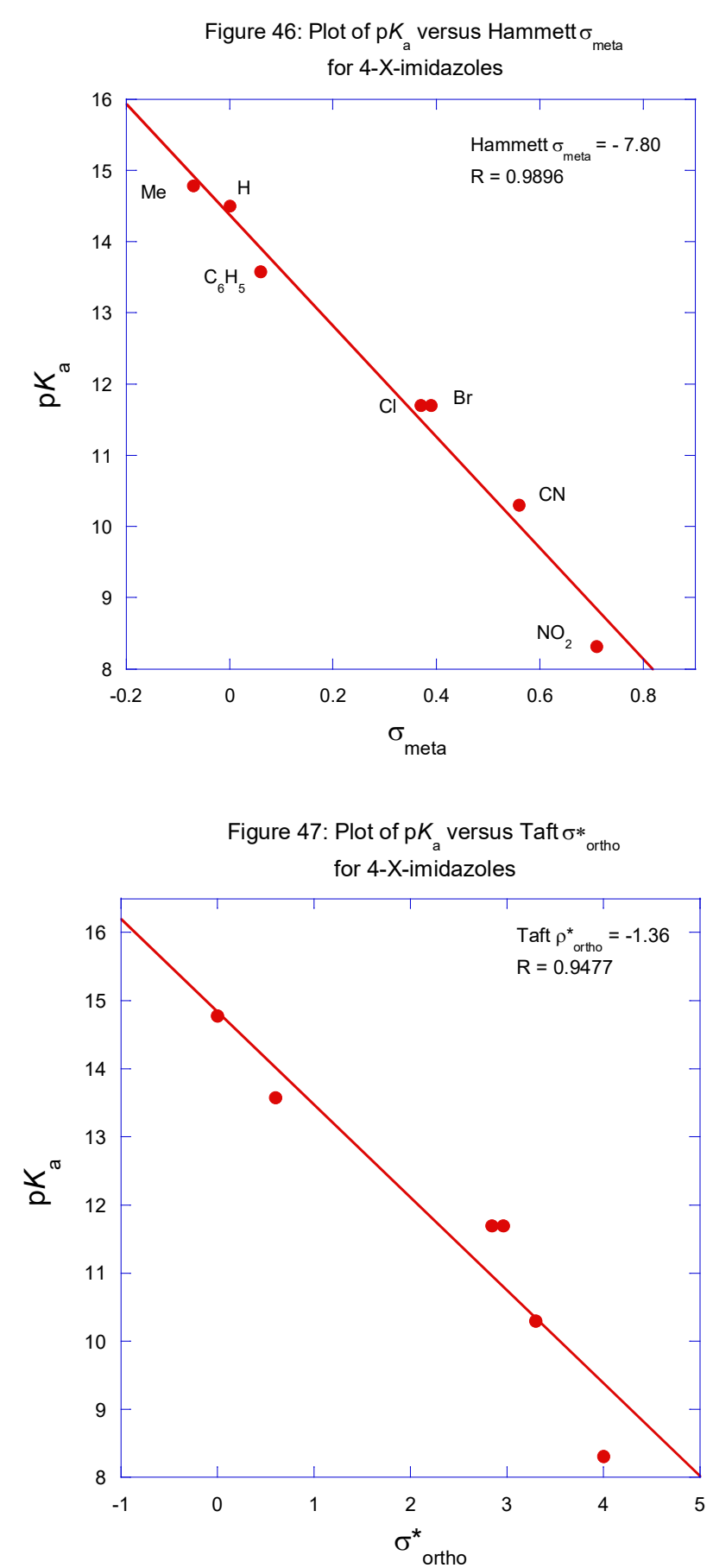

In the figures $45-47$ it is clear from the correlation coefficients, the $\mathrm{p} K_{\mathrm{a}}$ data of $4-\mathrm{X}$ imidazoles correlated well (Hammett $\left.\rho_{\text {meta }}=-7.80, \mathrm{R}=0.9896\right)$ with Hammett $\sigma_{\mathrm{m}}$ values. Therefore the 4 position of the 4 -X-imidazoles is best assumed as meta-position. The substituent effect may be better transmitted through the 5 positioned sp 2 carbon. 
Table 19: $\mathrm{p} K_{\mathrm{a}}$, Hammett $\sigma_{\mathrm{p}}, \sigma_{\mathrm{m}}$ and Taft $\sigma_{\text {ortho }}^{*}$ values of 3-X-1, 2, 4-triazole<smiles></smiles>

\begin{tabular}{|c|c|c|c|c|c|c|}
\hline \multirow{2}{*}{ Sl. No. } & \multirow{2}{*}{$\mathrm{X}$} & \multirow{2}{*}{$\mathrm{p} K_{\mathrm{a}}$} & \multicolumn{2}{|c|}{ Hammett } & \multirow{2}{*}{$\begin{array}{c}\text { Taft } \\
\sigma_{\text {ortho }}^{*}\end{array}$} & \multirow{2}{*}{ Literature for $\mathrm{p} K_{\mathrm{a}}$ values } \\
\hline & & & $\sigma_{\mathrm{p}}$ & $\sigma_{\mathrm{m}}$ & & \\
\hline 1 & $\mathrm{H}$ & 10.3 & 0.00 & 0.00 & 0.49 & https://en.wikipedia.org/wiki/1,2,4-Triazole\# \\
\hline 2 & $\mathrm{Cl}$ & 7.96 & 0.23 & 0.37 & 2.96 & $\begin{array}{l}\text { https://www.chemicalbook.com/ChemicalProductPrope } \\
\text { rty EN CB5132779.htm }\end{array}$ \\
\hline 3 & $\mathrm{Me}$ & 10.6 & -0.17 & -0.07 & 0.00 & $\begin{array}{l}\text { https://www.chemicalbook.com/ChemicalProductPrope } \\
\text { rty_EN_CB0692434.htm }\end{array}$ \\
\hline 4 & $\mathrm{Br}$ & 7.84 & 0.23 & 0.39 & 2.84 & $\begin{array}{l}\text { https://www.chemicalbook.com/ChemicalProductPrope } \\
\text { rty EN CB6770824.htm }\end{array}$ \\
\hline 5 & $\mathrm{CN}$ & 6.82 & 0.66 & 0.56 & 3.30 & $\begin{array}{l}\text { https://m.chemicalbook.com/ChemicalProductProperty } \\
\text { EN CB6344463.htm }\end{array}$ \\
\hline 6 & $\mathrm{NO}_{2}$ & 5.92 & 0.80 & 0.71 & 4.00 & $\begin{array}{l}\text { https://www.chemicalbook.com/ProductMSDSDetailC } \\
\text { B7448098 EN.htm }\end{array}$ \\
\hline 7 & $\mathrm{NH}_{2}$ & 11.1 & -0.66 & -0.16 & 0.62 & $\begin{array}{l}\text { https://www.chemicalbook.com/ChemicalProductPrope } \\
\text { rty EN CB6767936.htm }\end{array}$ \\
\hline
\end{tabular}

Figure 36: Plot of $\mathrm{pK}_{\mathrm{a}}$ versus Hammett $\sigma_{\text {para }}$ for 3-X-1, 2, 4-triazole

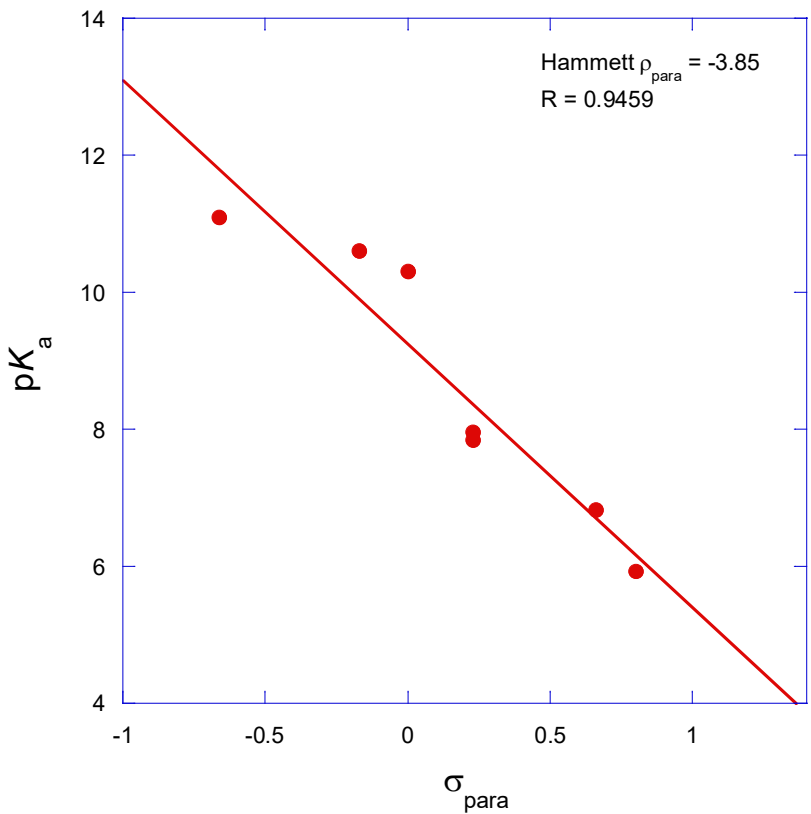



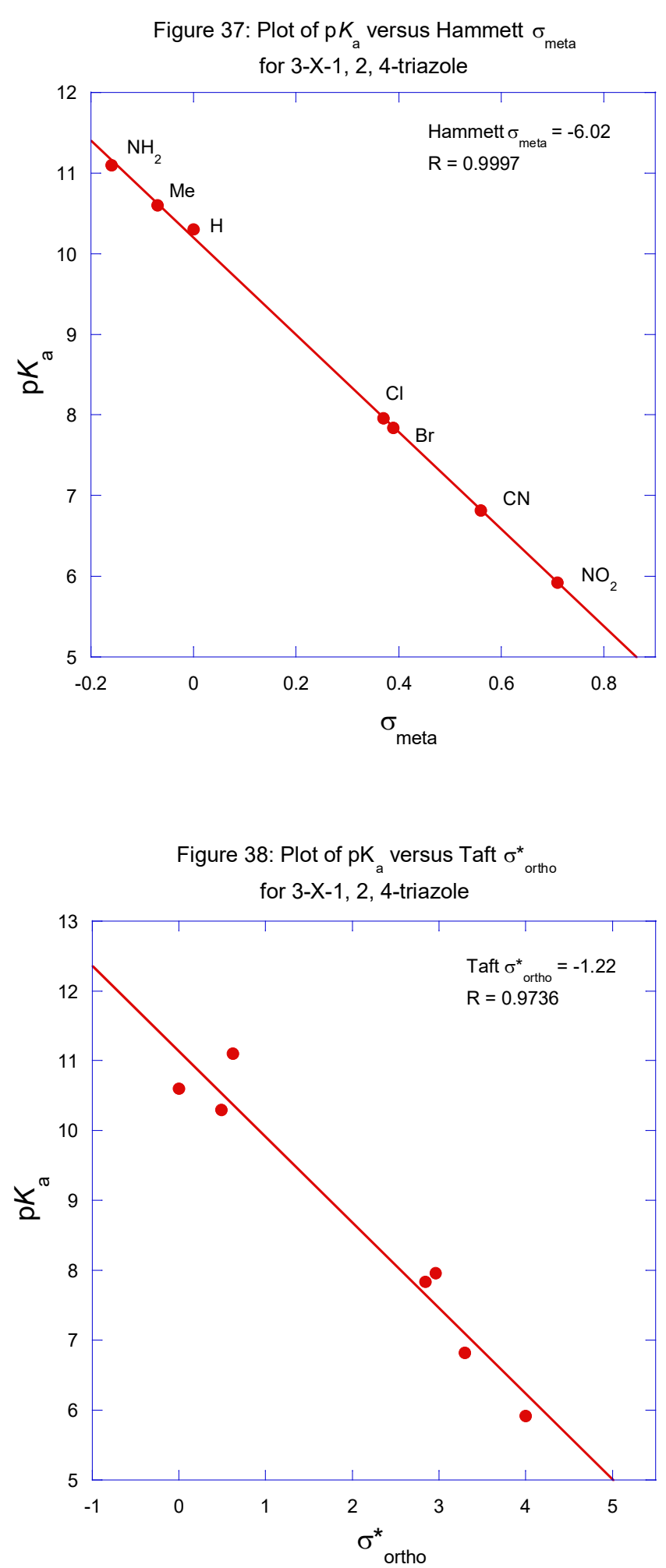

In the figures 36-38 it is clear from the correlation coefficients, the $\mathrm{p} K_{\mathrm{a}}$ data of $3-\mathrm{X}-1,2,4-$ triazole correlated well (Hammett $\left.\rho_{\mathrm{m}}=-6.02, \mathrm{R}=0.9997\right)$ with Hammett $\sigma_{\mathrm{m}}$ values. Therefore the 3 position of the 1-substituted $(\mathrm{N} 1 \mathrm{H}) 3-\mathrm{X}-1,2,4$-triazole is best assumed as meta-position. The situation here is analogous to the structure $\mathbf{F}$ of scheme 3 as shown below in scheme 13. 


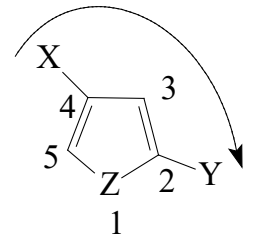

$4-\mathrm{X}-2-\mathrm{COOH}$

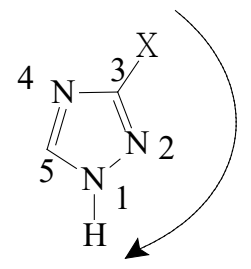

3-X-1,2,4-Triazol€

Structure $\mathbf{F}$ of scheme 3

Scheme 13

It is to be understood that when the substituent is at 2 position like $\mathrm{Y}$ in structure $\boldsymbol{F}$ of scheme 3, 4 position becomes meta. Similarly, when the substituent (N1H) is at 1 position like in 3-X-1,2,4-triazole, 3 position becomes meta.

4-X-1, 2, 3-triazole:

\begin{tabular}{|c|c|c|c|c|c|c|}
\hline \multicolumn{7}{|c|}{ Table 20: $\mathrm{p} K_{\mathrm{a}}$, Hammett $\sigma_{\mathrm{p}}, \sigma_{\mathrm{m}}$ and Taft $\sigma_{\text {ortho }}^{*}$ values of 4-X-1, 2, 3-triazole } \\
\hline \multicolumn{7}{|c|}{ 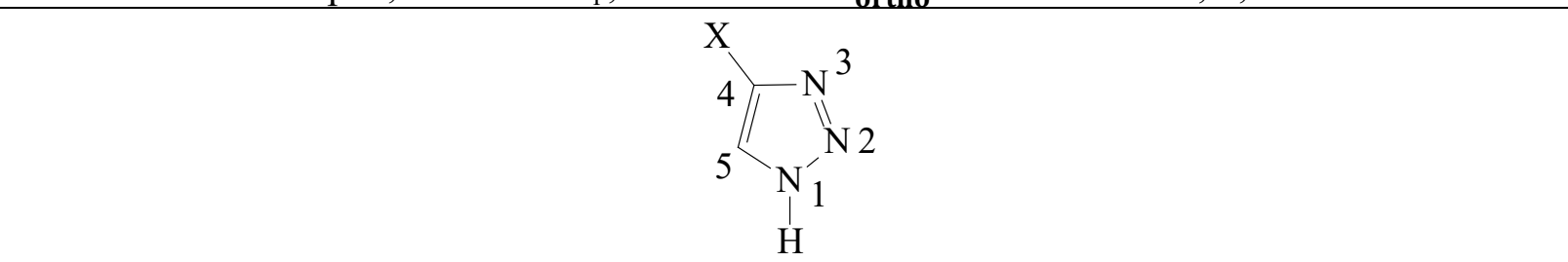 } \\
\hline \multirow{2}{*}{ S1. No. } & \multirow{2}{*}{$\mathrm{X}$} & \multirow{2}{*}{$\mathrm{p} K_{\mathrm{a}}$} & \multicolumn{2}{|c|}{ Hammett } & \multirow{2}{*}{$\begin{array}{c}\text { Taft } \\
\sigma_{\text {ortho }}^{*}\end{array}$} & \multirow{2}{*}{ Literature for $\mathrm{p} K_{\mathrm{a}}$ values } \\
\hline & & & $\sigma_{\mathrm{p}}$ & $\sigma_{\mathrm{m}}$ & & \\
\hline 1 & $\mathrm{H}$ & 9.40 & 0.00 & 0.00 & 0.49 & https://en.wikipedia.org/wiki/1,2,3-Triazole \\
\hline 2 & $\mathrm{Me}$ & 9.18 & -0.17 & -0.07 & 0.00 & $\begin{array}{l}\text { https://www.chemicalbook.com/ChemicalProd } \\
\text { uctProperty EN CB62468769.htm }\end{array}$ \\
\hline 3 & $\mathrm{Br}$ & 6.98 & 0.23 & 0.39 & 2.84 & $\begin{array}{l}\text { https://www.chemicalbook.com/ChemicalProd } \\
\text { uctProperty_EN_CB82520209.htm }\end{array}$ \\
\hline 4 & $\mathrm{NH}_{2}$ & 9.87 & -0.66 & -0.16 & 0.62 & $\begin{array}{l}\text { https://www.chemicalbook.com/ChemicalProd } \\
\text { uctProperty EN CB02460781.htm }\end{array}$ \\
\hline 5 & $\mathrm{C}_{6} \mathrm{H}_{5}$ & 7.68 & -0.01 & 0.06 & 0.60 & $\begin{array}{l}\text { H. Wamhoff, in Comprehensive Heterocyclic } \\
\text { Chemistry, 1984, Ed. By Alan R. Katritzky, } \\
\text { Elsevier. }\end{array}$ \\
\hline
\end{tabular}


Figure 39: Plot of $\mathrm{pK}_{\mathrm{a}}$ versus Hammett $\sigma_{\text {para }}$

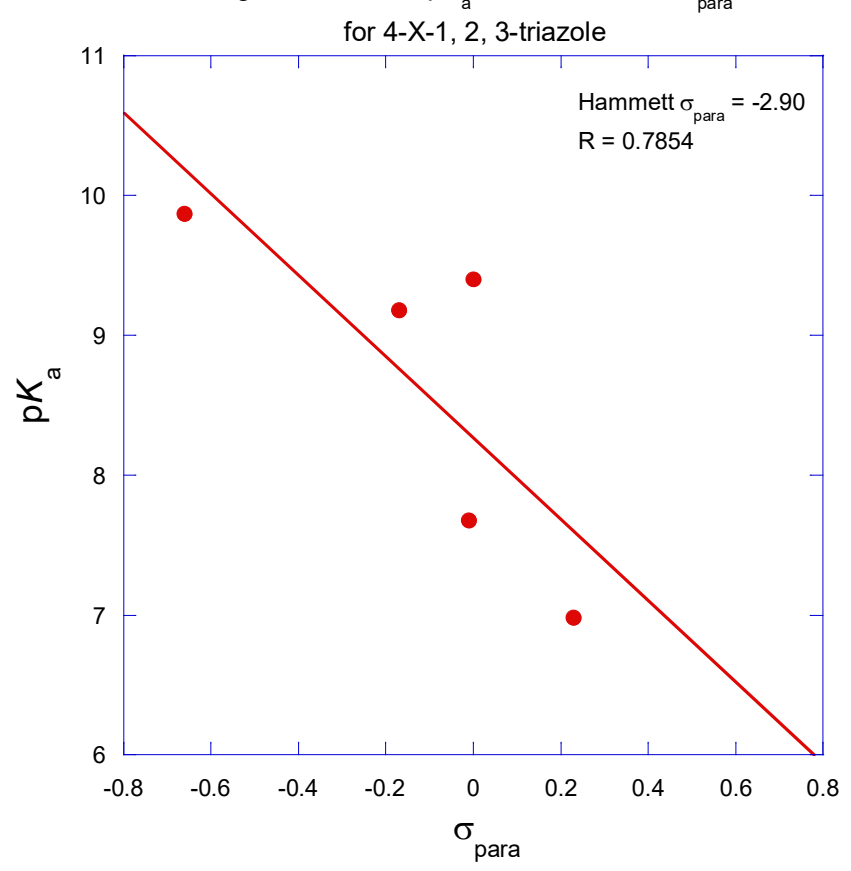

Figure 40: Plot of $\mathrm{p} K_{\mathrm{a}}$ versus Hammett $\sigma_{\text {meta }}$

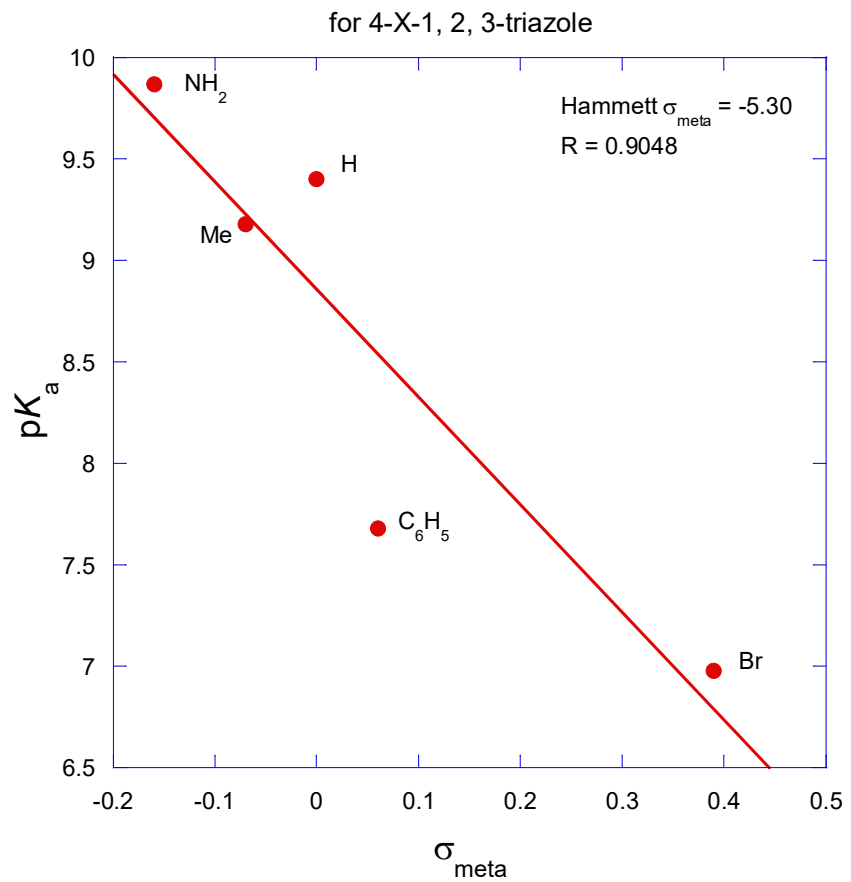




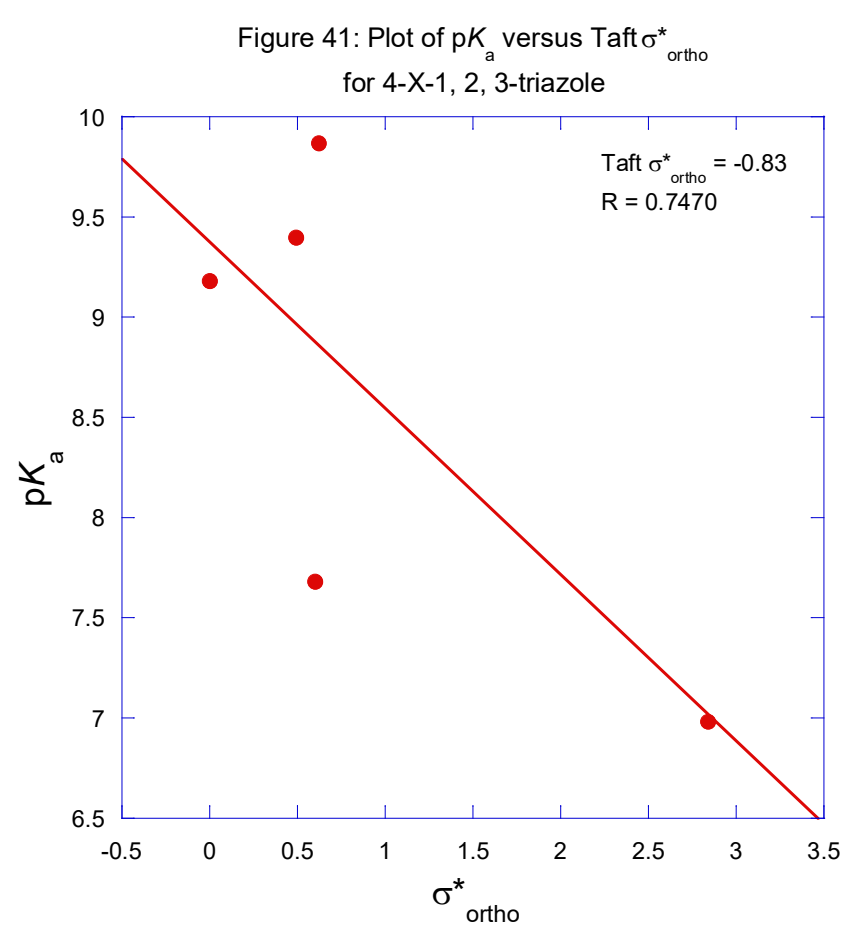

In the figures 39-41 it is clear from the correlation coefficients, the $\mathrm{p} K_{\mathrm{a}}$ data of $4-\mathrm{X}-1,2,3-$ triazole correlated well (Hammett $\rho_{\mathrm{m}}=-5.30, \mathrm{R}=0.9048$ ) with Hammett $\sigma_{\mathrm{m}}$ values. Therefore the 4 position of the 1-substituted $(\mathrm{N} 1 \mathrm{H}) 4-\mathrm{X}-1,2,3$-triazole is best assumed as meta-position. The situation again here is analogous to the structure $\mathbf{F}$ of scheme 3 as shown below in scheme 14 but in the opposite direction via carbon 5 .

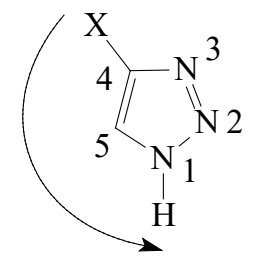

4-X-1,2,3-Triazol€

Scheme 14 
Table 21: $\mathrm{p} K_{\mathrm{a}}$, Hammett $\sigma_{\mathrm{p}}, \sigma_{\mathrm{m}}$ and Taft $\sigma_{\text {ortho }}^{*}$ values of 5-X-1, 2, 3, 4-tetrazoles<smiles></smiles>

1H-Tautomer

2H-Tautomer

\begin{tabular}{|c|c|c|c|c|c|c|}
\hline \multirow{2}{*}{ S1. No. } & \multirow{2}{*}{$\mathrm{X}$} & \multirow{2}{*}{$\mathrm{p} K_{\mathrm{a}}$} & \multicolumn{2}{|c|}{ Hammett } & \multirow{2}{*}{$\begin{array}{c}\text { Taft } \\
\sigma_{\text {ortho }}^{*}\end{array}$} & \multirow{2}{*}{ Literature for $\mathrm{p} K_{\mathrm{a}}$ values } \\
\hline & & & $\sigma_{p}$ & $\sigma_{\mathrm{m}}$ & & \\
\hline 1 & $\mathrm{H}$ & 4.86 & 0.00 & 0.00 & 0.49 & \multirow{11}{*}{$\begin{array}{l}\text { R. E. Trifonov and V. A. Ostrovskii, Russian } \\
\text { Journal of Organic Chemistry, 2006, Vol. 42, } \\
\text { No. 11, pp. 1585-1605 }\end{array}$} \\
\hline 2 & $\mathrm{Me}$ & 5.56 & -0.17 & -0.07 & 0.00 & \\
\hline 3 & $\mathrm{Et}$ & 5.59 & -0.15 & -0.07 & -0.1 & \\
\hline 4 & i-Pro & 5.53 & -0.15 & -0.07 & -0.19 & \\
\hline 5 & CF3 & 1.40 & 0.54 & 0.43 & 2.61 & \\
\hline 6 & $\mathrm{Cl}$ & 2.07 & 0.23 & 0.37 & 2.96 & \\
\hline 7 & $\mathrm{Br}$ & 2.13 & 0.23 & 0.39 & 2.84 & \\
\hline 8 & $\mathrm{I}$ & 2.85 & 0.28 & 0.35 & 2.46 & \\
\hline 9 & $\mathrm{NH}_{2}$ & 6.00 & -0.66 & -0.16 & 0.62 & \\
\hline 10 & $\mathrm{C}_{6} \mathrm{H}_{5}$ & 4.83 & -0.01 & 0.06 & 0.60 & \\
\hline 11 & $\mathrm{NO}_{2}$ & -0.83 & 0.80 & 0.71 & 4.00 & \\
\hline
\end{tabular}

Figure 42: Plot of $p K_{a}$ versus Hammett $\sigma_{\text {para }}$ for 5-X-1, 2, 3, 4-tetrazoles

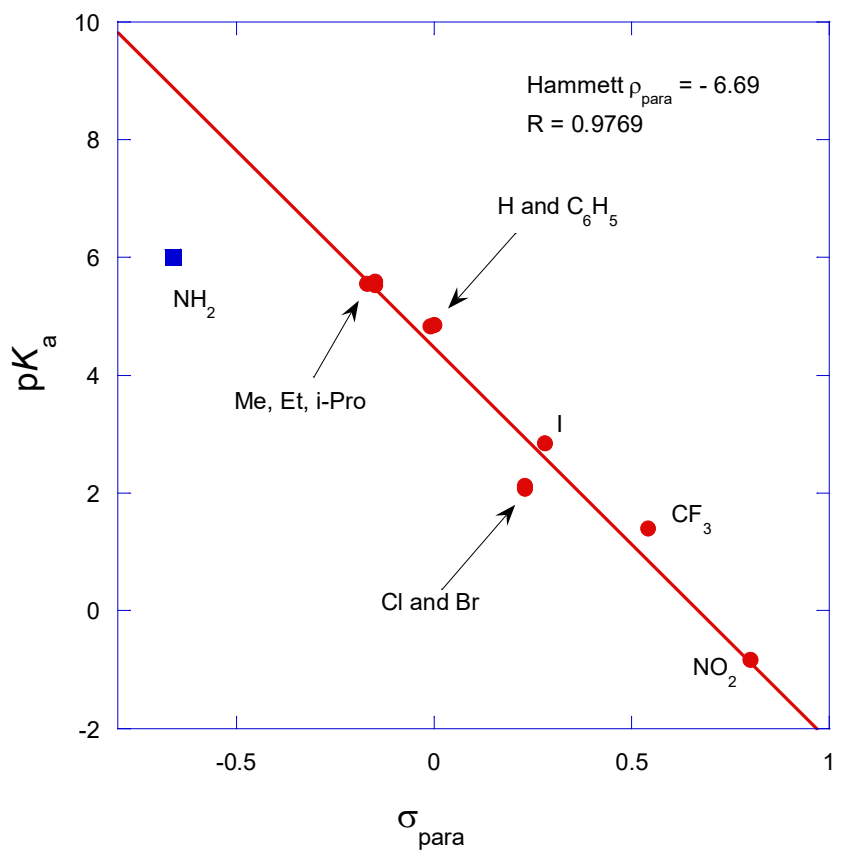


Figure 43: Plot of $p K_{a}$ versus Hammett $\sigma_{\text {meta }}$

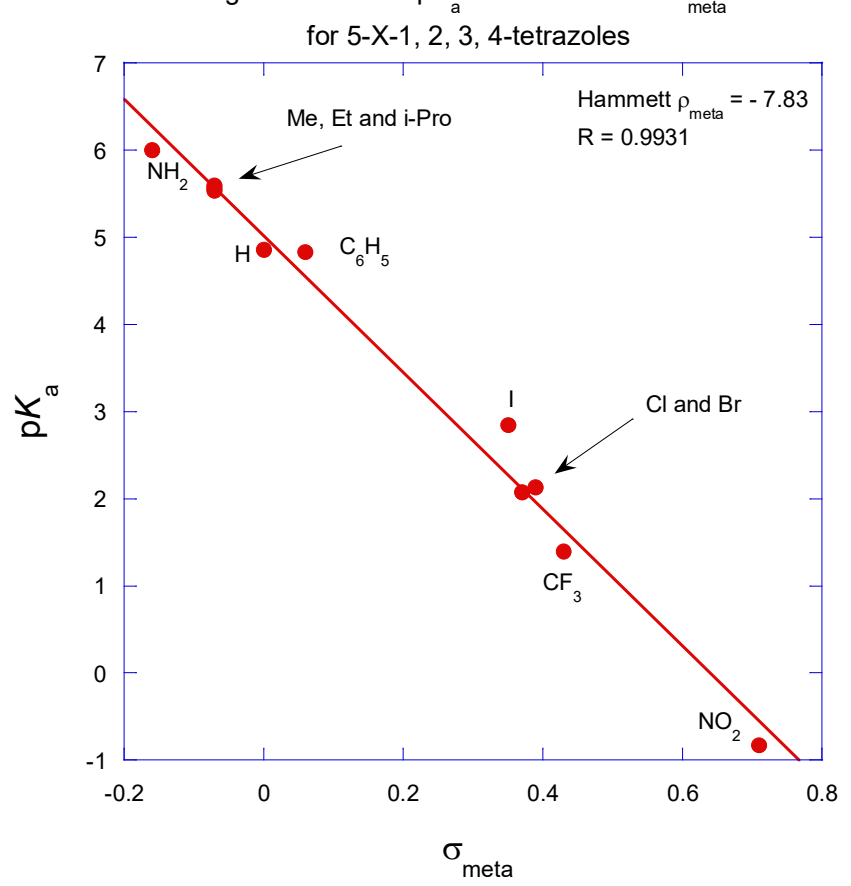

Figure 44: Plot of $p K_{a}$ versus Taft $\sigma *$ ortho for 5-X-1, 2, 3, 4-tetrazoles

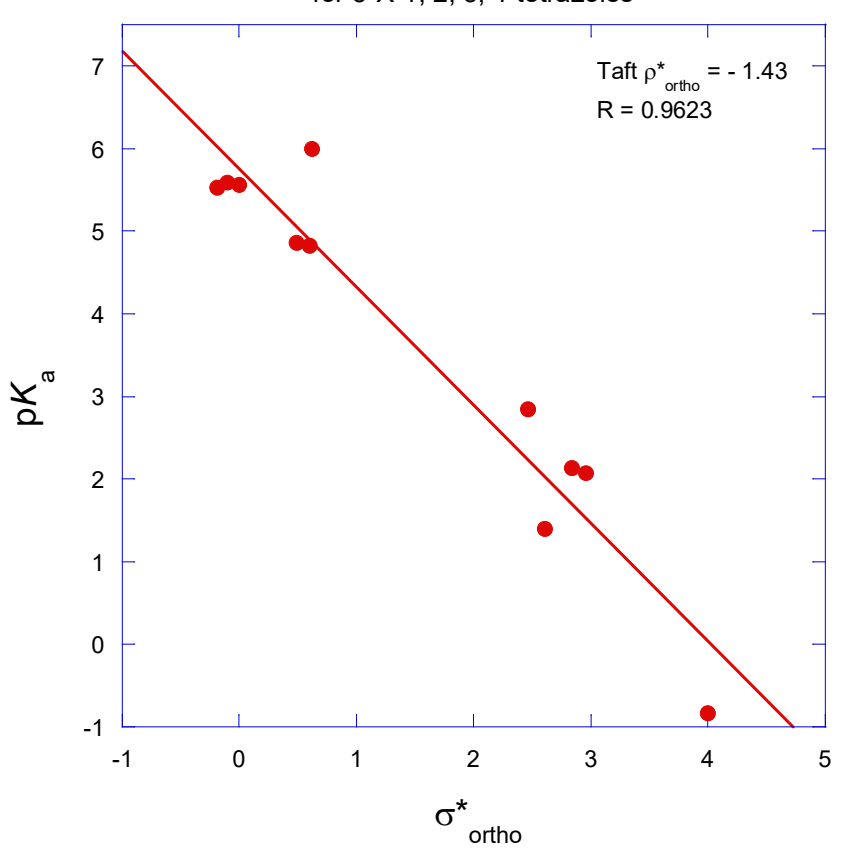




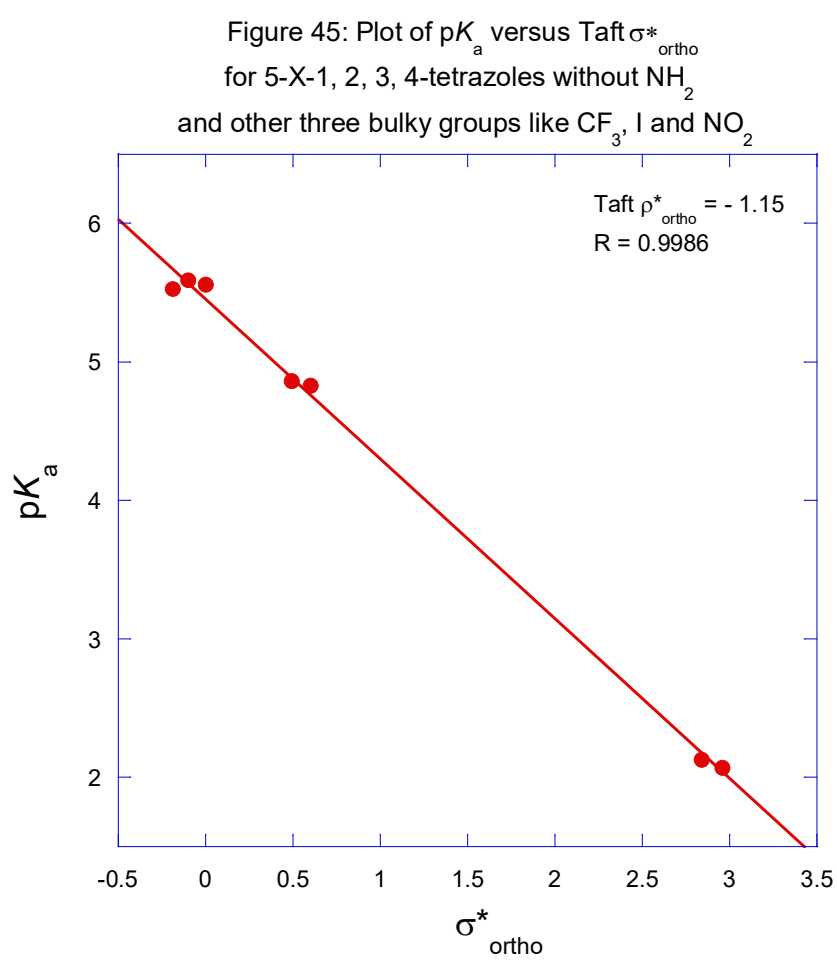

The effect of substituents $(\mathrm{X})$ on the $\mathrm{p} K_{\mathrm{a}}$ values of 5-X-1, 2, 3, 4-tetrazoles is rather complex [23]. Tetrazole itself is a strange molecule with $80 \%$ nitrogen of the total weight of the molecule. It is known that the tetrazole molecule exists in two tautomeric forms as shown in scheme 15 [24]. In a nonpolar medium, both the $1 \mathrm{H}$ and $2 \mathrm{H}$ tautomers are predicted to exist in comparable amounts. In the solvents like water with high dielectric constant the existence of more polar $1 \mathrm{H}$-tautomer is appreciable [24]. From figures 42-45, the correlation of $\mathrm{p} K_{\mathrm{a}}$ values with para and meta substituents is good $(\mathrm{R}=0.9769$ and 0.9931$)$ with a deviation of $\mathrm{NH}_{2}$ group with the para-susbtituents correlation.<smiles>[X]c1nnnn1[TlH]</smiles>

1H-Tautomer

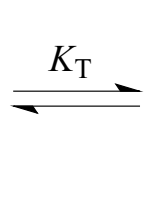<smiles></smiles>

2H-Tautomer

Scheme 15

Though the content of $2 \mathrm{H}$-tautomer is less than the $1 \mathrm{H}$-tautomer in more polar solvents (since the $\mathrm{p} K_{\mathrm{a}}$ values are from water as the solvent [23]), yet the para and meta substituent effects originate from less abundant $2 \mathrm{H}$-tautomer. If one looks at the $2 \mathrm{H}$-tautomer (scheme 15), the functional group ( $\mathrm{N} 2-\mathrm{H})$ is at meta to $\mathrm{X}$ at position 5 via nitrogen 1 and it will be para to $\mathrm{X}$ at position 5 via nitrogen 3 and 4 . This is just like the visual observation for defining the para and meta positions of 5 membered heterocycles as given in scheme 2 and scheme 3 . This is 
the reason that the $\mathrm{p} K_{\mathrm{a}}$ values are well correlated with both Hammett $\sigma_{\text {para }}$ and $\sigma_{\text {meta }}$ substituent constants. The deviation of $\mathrm{NH}_{2}$ in the correlation with para substituents may be due to the intramolecular hydrogen bonding as shown in scheme 16 .

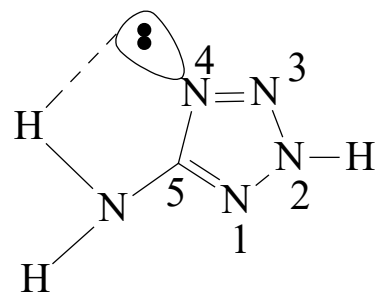

Scheme 16

From Taft plots given in figures 44 and 45 it may be assumed that the ortho-substituent effects originate from $1 \mathrm{H}$-tautomer. If one looks at the $1 \mathrm{H}$-tautomer (scheme 15), the functional group (N1-H) is at ortho to $\mathrm{X}$ adjacent to nitrogen 1 . This is just similar to the visual observation for defining the ortho position of 5 membered heterocycles as given in scheme 4. Also, it is noteworthy to see the correlation is improved without the bulky groups like $\mathrm{CF}_{3}$, I and $\mathrm{NO}_{2}$ (figure 45).

Table 22 gives a quick glance of the whole work. The readers should note that the Hammett and Taft reaction constants ( $\rho$ and $\rho^{*}$ ) are given as positive numbers though as they were obtained as negative numbers in the plots because the plots were done using $\mathrm{p} K_{\mathrm{a}}(=-\log$ $\left.K_{\mathrm{a}}\right)$ values. 
Table 22: Hammett and Taft parameters of different systems

\begin{tabular}{|c|c|c|c|c|c|c|c|c|}
\hline \multirow{2}{*}{$\begin{array}{l}\text { Sl. } \\
\text { No. }\end{array}$} & \multirow{2}{*}{ Heterocycle } & \multirow{2}{*}{$\begin{array}{l}\text { Number } \\
\text { of } \\
\text { substitu } \\
\text {-ents } \\
\end{array}$} & \multicolumn{2}{|c|}{ Hammett } & \multirow{2}{*}{$\frac{\text { Taft }}{\rho *_{\text {ortho }}}$} & \multicolumn{3}{|c|}{ Correlation coefficients with } \\
\hline & & & $\rho$ para & Pmeta & & $\sigma_{\text {para }}$ & $\sigma_{\text {meta }}$ & $\sigma^{*}$ ortho \\
\hline 1 & $\mathrm{x}_{\substack{\mathrm{O} \\
\text { 5-X-Furan-2-COOH }}}^{3} \mathrm{~s}$ & 8 & 1.38 & 1.72 & 0.300 & 0.9982 & 0.9469 & 0.8953 \\
\hline 2 & 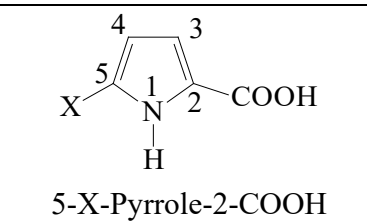 & 8 & 1.54 & 1.79 & 0.295 & 0.9873 & 0.8664 & 0.7630 \\
\hline 3 & $\mathrm{X}_{\substack{\mathrm{S} \\
\text { 5-X-Thiophene-2-COOH }}}^{3} \mathrm{5}$ & 8 & 1.06 & 1.34 & 0.209 & 0.9939 & 0.8657 & 0.7345 \\
\hline 4 & 5-X-Tellurophene-2-COOH & 5 & 1.59 & 2.08 & 0.381 & 0.9303 & 0.9778 & 0.9566 \\
\hline 5 & 4-X-Pyrrole-2-COOH & 5 & 1.32 & 1.50 & 0.263 & 0.9931 & 0.9824 & 0.9352 \\
\hline 6 & $\underset{4}{4,5-\mathrm{X} \text {-Isoxazole-3-COOH }}$ & 5 & & & 0.584 & & & 0.9924 \\
\hline 7 & 3,5-X-Isoxazole-4-COOH & 5 & & & 0.459 & & & 0.9964 \\
\hline 8 & 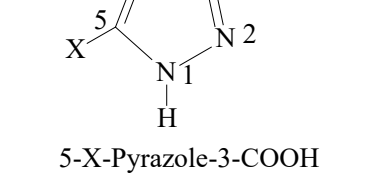 & 3 & 0.884 & 1.04 & 0.188 & 0.9723 & 0.9988 & 0.9742 \\
\hline 9 & $\begin{array}{c}\mathrm{N}_{1} \\
\mathrm{CH}_{3} \\
\text { 4,5-X-Pyrazole-3-COOH }\end{array}$ & 3 & & Correlat & is not & ood with & m (figure & \\
\hline
\end{tabular}




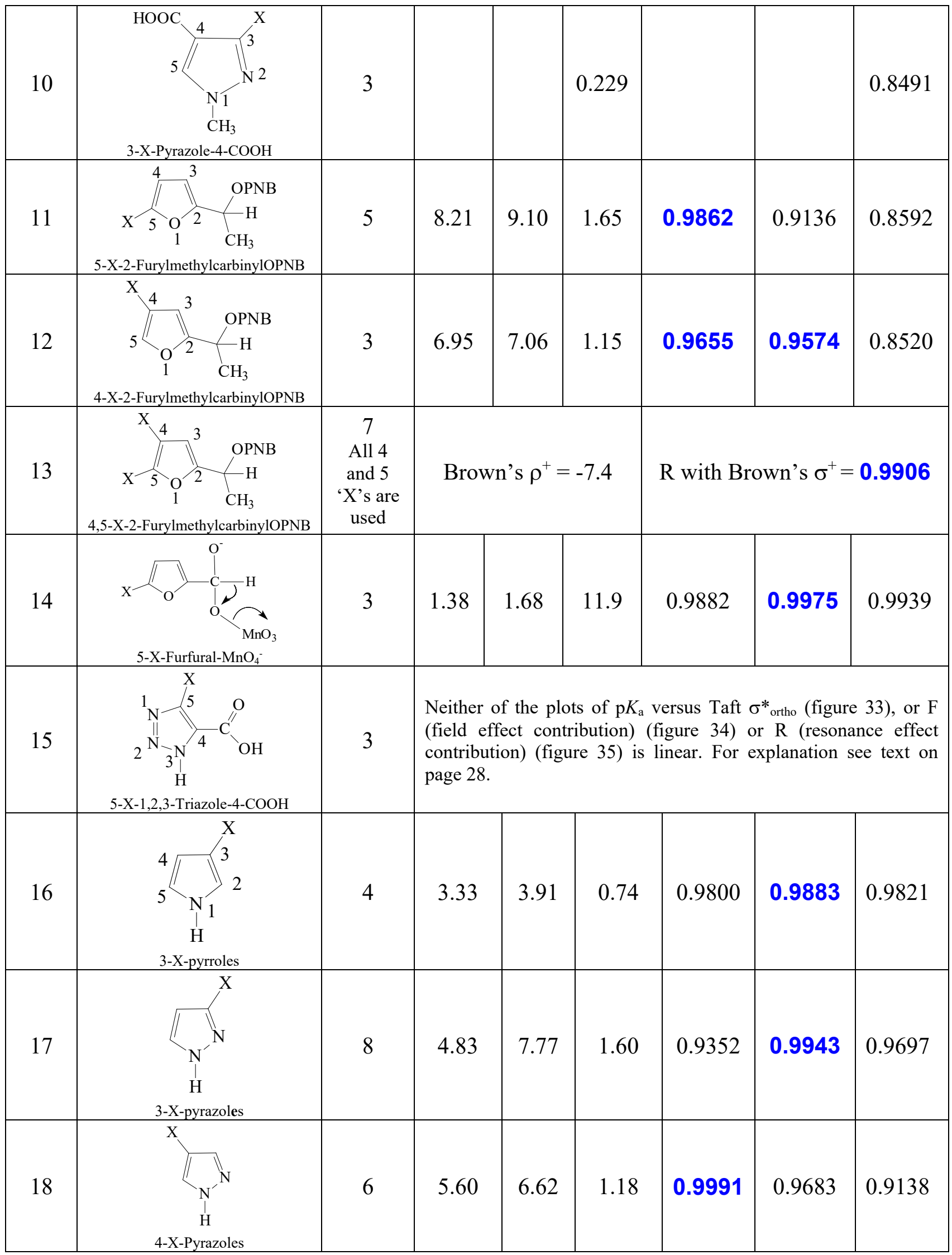




\begin{tabular}{|c|c|c|c|c|c|c|c|c|}
\hline 19 & $\sum_{\text {4-X-Imidazoles }}^{\mathrm{X}}$ & 7 & 6.32 & 7.80 & 1.36 & 0.9696 & 0.9896 & 0.9477 \\
\hline 20 & 3-X-1,2,4-Triazole & 7 & 3.85 & 6.02 & 1.22 & 0.9459 & 0.9997 & 0.9736 \\
\hline 21 & ${ }_{4-\mathrm{X}-1,2,3 \text {-Triazole }}^{\mathrm{X}}$ & 5 & 2.90 & 5.30 & 0.83 & 0.7854 & 0.9048 & 0.7470 \\
\hline 22 & 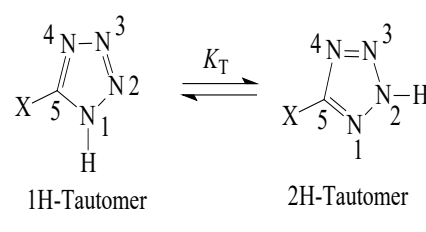 & 11 & 6.69 & 7.83 & 1.43 & 0.9769 & 0.9931 & 0.9623 \\
\hline
\end{tabular}




\section{References}

1. Hammett. L. P., J. Am. Chem. Soc., vol. 59, page 96 (1937)

2. Hammett. L. P., "Physical Organic Chemistry." McGraw Hill Book Co., Inc., New York, 1940, P. 184

3. Jaffe, H. H, Chem. Rev., IS, 191 (1953)

4. Wells, P. R., Chem. Rev., 83, 171 (1963)

5. Taft, R. W. J. Am. Chem. Soc. 1952, 74, 2729 and 3120.

6. Taft, R. W. J. Am. Chem. Soc. 1953, 75, 4538.

7. L. P. Hammett, Chem. Revs., vol. 17, page 125, 1935

8. Imoto, E. and Motoyama, R., Bull. Naniwa Univ., Series A. 2. 127 (1954)

9. F. Freeman, J. Chem. Edn., vol. 47, page 140, 1970

10. Catlin, W.E., Iowa State Coll. J.Sci.,10, 65 (1935)

11. Salo Gronowitz, Thiophene and its derivatives part 2 in The Chemistry of Heterocyclic Compounds, an Interscience publication, 1986 by John Wiley \& sons, Inc.

12. A. Kekulé, Justus Liebigs Ann. Der Chemie, Vol. 162, page 77-124, 1872, https://en.wikipedia.org/wiki/Benzene\#cite note-18

13. Melander L. Ark. Kemi, 11, 397 (1957)

14. Ram Keswani and Henry Freis, J. Am. Chem. Soc.,71, I789 (1949)

15. (a) H. Spiesecke and W. G. Schneider, J. Chem. Phys., 35, 731 (1961), (b) Tetrahedron Letters, 468, 1961

16. A. Halasa, L. Lapinski, I. Reva, H. Rostkowska, R. Fausto, and M. J. Nowak, J. Phys. Chem. A 2015, 119, 1037-1047

17. Advances in heterocyclic chemistry, Ed. A. R. Katritzky and A. J. Boulton, Vol. 20, page 37, Academic Press, New York, 1976

18. Zhou P, Tian F, Lv F, Shang Z., Proteins, 2009, 76, page 151-63

19. The bacterial response to the chalcogen metalloids Se and Te by D. Zannoni, F. Borsetti, J. J. Harrison and R. J. Turner in Advances in microbial physiology, Ed. By Robert K. Poole, Academic Press, First Edition 2008, page 4.

20. Donald S. Noyce and Gary V. Kaiser, J. Org. Chem., vol. 34, page 1008, 1969

21. F. Freeman, J. B. Brant, N. B. Hester, A. A. Kamego, M. Kasner, T. G. Mclaughlin, and E. W. Paull, The Journal of Organic Chemistry, vol. 35, page 985, 1970

22. C. G. Swain and E. C. Lupton, Jr., Journal of the American Chemical Society, 90,4328, 1968 
23. R. E. Trifonov and V. A. Ostrovskii, Russian Journal of Organic Chemistry, 2006, Vol. 42, No. 11, pp. 1585-1605

24. Ming Wah Wong, Regis Leung Toung and Curt Wentrup, J . Am. Chem. Soc. 1993, 115, 2465-2472 